\title{
Normal Performance of Fmr1 Mice on a Touchscreen Delayed Nonmatching to Position Working Memory Task ${ }^{1,2,3}$
}

\author{
Prescott T. Leach, Jane Hayes, Michael Pride, Jill L. Silverman, and Jacqueline N. Crawley
}

DOI:http://dx.doi.org/10.1523/ENEURO.0143-15.2016

Department of Psychiatry and Behavioral Sciences, MIND Institute, University of California, Davis, School of Medicine, Sacramento, California 95817

\begin{abstract}
Fragile $\mathrm{X}$ syndrome is a neurodevelopmental disorder characterized by mild-to-severe cognitive deficits. The complete absence of $F m r 1$ and its protein product in the mouse model of fragile $\mathrm{X}$ ( Fmr1 KO) provides construct validity. A major conundrum in the field is the remarkably normal performance of Fmr1 mice on cognitive tests in most reports. One explanation may be insufficiently challenging cognitive testing procedures. Here we developed a delayed nonmatching to position touchscreen task to test the hypothesis that paradigms placing demands on working memory would reveal robust and replicable cognitive deficits in the Fmr1 KO mouse. We first tested Fmr1 KO mice (Fmr1) and their wild-type (WT) littermates in a simple visual discrimination task, followed by assessment of reversal learning. We then tested Fmr1 and WT mice in a new touchscreen nonmatch to position task and subsequently challenged their working memory abilities by adding delays, representing a higher cognitive load. The performance by Fmr1 KO mice was equal to WTs on both touchscreen tasks. Last, we replicated previous reports of normal performance by Fmr1 mice on Morris water maze spatial navigation and reversal. These results indicate that, while the Fmr1 mouse model effectively recapitulates many molecular and cellular aspects of fragile $X$ syndrome, the cognitive profile of Fmr1 mice generally does not recapitulate the primary cognitive deficits in the human syndrome, even when diverse and challenging tasks are imposed.
\end{abstract}

Key words: cognition; fragile X; learning and memory; mouse model; touchscreen; working memory

\section{Significance Statement}

Traditional cognitive tests have revealed surprisingly normal performance in the Fmr1 knock-out mouse model (Fmr1) of fragile X syndrome (FXS). Here we introduce novel methods for conducting working memory tasks, following discrimination and reversal learning tasks, to interrogate $F m r 1$ mice with a diverse set of cognitive challenges. Touchscreen technology, incorporating direct analogies to methods used to evaluate cognitive abilities in human subjects and nonhuman primates, was used to evaluate Fmr1 mice on simple pairwise discrimination, reversal, nonmatching to position, and delayed nonmatching to position. No significant deficits were detected in Fmr1 mice, supporting the interpretation that this widely used mouse model of FXS is not optimal for discovering pharmacological therapeutics that improve cognitive functioning in individuals with FXS. 


\section{Introduction}

Fragile $X$ syndrome $(F X S)$ is a genetic disorder caused by a hypermethylated FMR1 gene, which reduces expression of fragile $X$ mental retardation protein (FMRP; Sutcliffe et al., 1992; Feng et al., 1995). FXS confers intellectual disability in domains such as working memory, executive function, short-term visual memory, visuospatial processing, sequence processing, and attention (Cianchetti et al., 1991; Freund and Reiss, 1991; Maes et al., 1994; Kogan et al., 2009; Baker et al., 2011). To understand the biological consequences of the absence of FMRP, The Dutch-Belgian Fragile X Consortium (1994) generated the Fmr1 knock-out (KO) mouse (Fmr1) in 1994. This genetic mouse model of FXS has been extensively used to investigate the functional outcomes of loss of Fmr1. Surprisingly, cognitive deficits in Fmr1 mice have proven remarkably mild and somewhat inconsistent across publications (Kooy, 2003). Background strain (Paradee et al., 1999; Dobkin et al., 2000; Spencer et al., 2011) and testing protocol differences across laboratories may explain the lack of well replicated learning and memory impairments in Fmr1 mice in some cases. However, given the primary symptom of intellectual disability in humans with FXS, cognitive deficits in Fmr1 KO mice were expected to be robust enough to withstand some variability in methods, background genetics, and environmental issues. It is important to know whether the results from the Fmr1 mouse are informative for the development of treatments for FXS or whether other models would allow greater predictive validity.

Recently, touchscreen behavioral testing equipment ideal for evaluating complex learning and memory in rodents was introduced by Bussey et al. (2001) at the University of Cambridge and rigorously validated in mice by Brigman and Rothblat (2008) and others (Bussey et al., 2012; Mar et al., 2013; Oomen et al., 2013; Graybeal et al., 2014). Visually based, touch-sensitive technology in operant chambers is similar to cognitive testing designs in higher-order species, including nonhuman primates and humans (Green et al., 2009; Van der Molen et al., 2010;

Received November 23, 2015; accepted February 10, 2016; First published February 24, 2016.

${ }^{1}$ The authors declare no competing financial interests.

${ }^{2}$ Author contributions: P.T.L., J.L.S., and J.N.C. designed research; P.T.L., J.H., and M.P. performed research; P.T.L. and J.L.S. analyzed data; P.T.L. and J.N.C. wrote the paper.

${ }^{3}$ This work was supported by National Institutes of Health Grants 1R01-NS085709 (P.T.L. and J.N.C.) and U54-HD-079125 (J.L.S. and J.N.C.), and Autism Speaks Targeted Grant 8703 (J.H., M.P., J.L.S., and J.N.C.)

Acknowledgments: The authors express their sincere appreciation to Drs. Gary Lynch, Christine Gall and Julie Lauterborn for their insightful discussions during the planning of these studies. We thank Kyle Puhger for his guidance in touchscreen procedures; and Dr. Tatiana Kazdoba, Kamela Sison, Heather Boyle, Karyn Tschida, and Justin Graham for their assistance in components of the methods including food restriction.

Correspondence should be addressed to Dr. Prescott T. Leach, Biogen, Inc., 125 Broadway, Cambridge, MA 02142. E-mail: prescott.leach@biogen.com. DOI:http://dx.doi.org/10.1523/ENEURO.0143-15.2016

Copyright (C) 2016 Leach et al.

This is an open-access article distributed under the terms of the Creative Commons Attribution 4.0 International, which permits unrestricted use, distribution and reproduction in any medium provided that the original work is properly attributed. van Nieuwpoort et al., 2011; Berry-Kravis et al., 2013; Díez-Juan et al., 2014). Investigations using mouse touchscreen chambers have recently been published by several behavioral neuroscience laboratories (Brigman et al., 2005; Talpos et al., 2010; Graybeal et al., 2011, 2014; Romberg et al., 2011; Bussey et al., 2012; Silverman et al., 2015). The touchscreen technology offers the possibility of designing cognitive tasks with increasing difficulty to challenge specific cognitive domains affected by neurodevelopmental disorders, such as working memory. Working memory tasks, such as delayed nonmatching to position can be conducted in rodents using automated operant technology (Estapé and Steckler, 2002; Martin et al., 2004; Dowdy-Sanders and Wenger, 2006; Krueger et al., 2006, 2009; Bernardo et al., 2007; Goto et al., 2010a,b; Whitney and Wenger, 2012). The few reports of working memory in Fmr1 mice have used radial arm maze, reporting mild reference memory deficits on the first 3 training days (Yan et al., 2004), and Morris water maze serial reversal learning, reporting reversal deficits (Baker et al., 2010). Touchscreen-based tasks, in which the mouse performs more naturalistic touching of the nose to the front panel instead of performing a lever press, has begun to be applied to Fmr1 mice (Dickson et al., 2013).

We hypothesized that challenging touchscreen paradigms of working memory would detect cognitive deficits in Fmr1 mice that were not detectable with arguably simpler tasks in the literature. The present experiments were designed with the following two goals in mind: (1) to optimize parallels with human FXS testing equipment, such as the Cambridge Neuropsychological Test Automated Battery (CANTAB), which has been successfully used in subjects with intellectual disability (Green et al., 2009; van Nieuwpoort et al., 2011) including FXS (Van der Molen et al., 2010; Berry-Kravis et al., 2013); and (2) to identify cognitive deficits in tasks that include the capacity to increase demands on working memory. Increasing the working memory load by introducing long delays was designed to determine whether the normal performance of Fmr1 mice on the tasks previously used may have been due to the insufficiently challenging nature of standard learning and memory tasks commonly used in mice or the specific cognitive modalities used in those tasks. Further, a comparison of recognition memory, working memory, and spatial navigation with the Morris water maze could reveal novel insights as to the cognitive profile of $F m r 1 \mathrm{KO}$ mice. Analogous CANTAB testing in humans with FXS revealed mean mental ages ranging from $4.53 \pm 0.59$ to $7.38 \pm 2.83$ years compared with chronological ages ranging from $25.65 \pm 7.41$ to $30.13 \pm 8.97$ years on visuospatial short term memory (sequential), working memory (self-ordered search), spatial recognition memory, recognition memory (instant recall), and recognition memory (delayed recall; Van der Molen et al., 2010). Strong cognitive deficits in an Fmr1 mouse model in a task with face validity to touchscreen methods used in humans with FXS would offer a novel preclinical research tool to test compounds for therapeutic efficacy. 


\section{Materials and Methods}

\section{Subjects}

Breeding pairs of $F m r 1$ knock-out mice (Fmr1) on the FVB Pde6b + Tyrc-ch/AntJ background with normal vision (catalog \#004624), the background inbred strain FVB Pde6b + Tyrc-ch/AntJ (FVB/AntJ; catalog \#004828) with normal vision, and male C57BL/6J (B6) mice (catalog \#000664) were purchased from The Jackson Laboratory. Mice were bred and maintained in an AAALAC-accredited vivarium on a conventional lighting schedule, with temperature and humidity controls. Offspring were weaned at $21 \mathrm{~d}$ of age, and were housed with littermates by sex in mixed-genotype cages, with two to four mice per cage. Fmr1 and their wild-type (WT) littermates were maintained on the FVB/AntJ background. The breeding scheme was Fmr1 heterozygous females $\times$ WT males. Genotyping was conducted using a Bio-Rad thermocycler and REDExtract-N-Amp PCR ReadyMix (catalog \#R4775, Sigma-Aldrich) with primers targeting the WT (TGT GAT AGA ATA TGC AGC ATG TGA), mutated (CAC GAG ACT AGT GAG ACG TG), and common primer sequences (CTT CTG GCA CCT CCA GCT T). Genotypes were recorded in a notebook with corresponding subject mouse identification (ID) numbers. At weaning, each mouse was assigned a unique cage card ID number that did not include mouse ID numbers or genotype. Experimenters were aware of only the unique cage card ID number when testing mice, thereby preventing bias by the researcher.

Male Fmr1 $(\mathrm{y} /-)$ and male WT littermates $(\mathrm{y} /+)$ were used for the touchscreen and water maze experiments. Control experiments were conducted with the inbred strains B6 and FVB/AntJ. Behavioral testing was conducted during the light phase, between 9:00 A.M. and 5:00 P.M. Prior to touchscreen testing and during water maze testing, mice were maintained in the same postweaning cages, in the same vivarium, and were allowed ad libitum access to food and water. Food restriction for the touchscreen experiments was initiated at 8-16 weeks of age, beginning $\sim 1$ week before the start of habituation. Eighty-five to $90 \%$ of free-feeding body weight was maintained throughout the touchscreen testing period. All procedures were approved by the University of California, Davis, Institutional Animal Care and Use Committee, and followed the National Institutes of Health Guide for the Care and Use of Laboratory Animals.

\section{Touchscreen apparatus}

Bussey-Saksida touchscreen chambers and software, manufactured by Campden Instruments, were purchased from Lafayette Instruments. Boxes were trapezoidal to enhance the focus of attention on the front screen, fitted with a Plexiglas two-hole mask (pairwise discrimination) or a five-hole mask (nonmatch). Screen covers contained $4 \times 4 \mathrm{~cm}$ openings (five-hole mask) or $8 \times 8 \mathrm{~cm}$ openings (two-hole mask) in which visual images were projected. Each touchscreen box contained a peristaltic pump that delivered a liquid reinforcement of $20 \mu \mathrm{l}$ of Ensure strawberry milkshake, diluted $1: 1$ with distilled $\mathrm{H}_{2} \mathrm{O}$, into a food magazine located on the back of the touchscreen chamber. Mice were loaded into the chambers based on their unique cage card ID numbers, and software automatically ran the program and collected response data, thus preventing the introduction of any observer bias by the investigator.

The testing sequence is illustrated in Figure 1, and described below.

\section{Pairwise visual discrimination \\ Pretraining}

Each subject mouse was habituated to the touchscreen boxes prior to operant training. During habituation, the food magazine was initially filled with reinforcer and signaled with a small LED located directly above the food magazine. Each nosepoke in the food magazine initiated a new habituation trial, which consisted of a $10 \mathrm{~s}$ intertrial interval (ITI) and delivery of the $20 \mu \mathrm{l}$ of reinforcer. Mice were habituated until 100 trials were reached in a $1 \mathrm{~h}$ period or until a clear pattern of increasing trials was observed for $3 \mathrm{~d}$. Following habituation, mice received fixed-ratio (FR-1) training, where each touch to a randomly presented visual image on the screen was reinforced and paired with a brief auditory cue that acts as a conditioned stimulus (CS). Image location varied randomly between the left and right screen locations. The first day of FR-1 training had no scheduled contingencies for touching the blank image location. Trials resulted in presentation of a reinforcer either upon touching the image or after $30 \mathrm{~s}$, whichever came first. Subsequently, mice received $\mathrm{FR}-1$ training, which removed the $30 \mathrm{~s}$ contingency for automatic reinforcer presentation, such that only touches to the image resulted in the presentation of a reinforcer. Mice remained on this phase until they had received 30 reinforcers in a single session. The third phase of FR-1 incorporated the contingency of a food magazine entry to initiate each trial. Mice remained on this phase until they had received 30 reinforcers in a single session. The fourth phase of FR-1 added a $10 \mathrm{~s}$ punished timeout in the event of a blank image touch. An ITI of 20 $s$ followed both correct and blank image touches. Software automatically calculated the percentage correct performance scores as \#Image touches $\div$ \#Image touches + \#blank touches. Training continued for $2 \mathrm{~d}$.

\section{Pairwise discrimination acquisition}

Mice were trained in pairwise visual discrimination using methods based on previous seminal publications (Bussey et al., 2001; Brigman et al., 2008, 2009; Graybeal et al., 2014; Silverman et al., 2015). Pairwise visual discrimination training trials had two distinct images randomly presented in the image locations. Mice were assigned to be reinforced for touches to the correct screen image $(S+)$ and punished with a $10 \mathrm{~s}$ timeout for touches to the other image (S-). The two images were an $\mathrm{X}$ or an $=$, which were matched for illumination and pseudorandomly assigned to individual mice as they finished pretraining. Approximately half of each genotype were assigned to $X$ (four WT and four Fmr1 mice), and the others were assigned to $=(4 \mathrm{WT}$ and $3 \mathrm{Fmr} 1)$ as the initial reinforced stimulus. Incorrect trials led to correction trials, which were identical to the previous trial in all ways. Responses on the correction trials were not included in the perfor- 


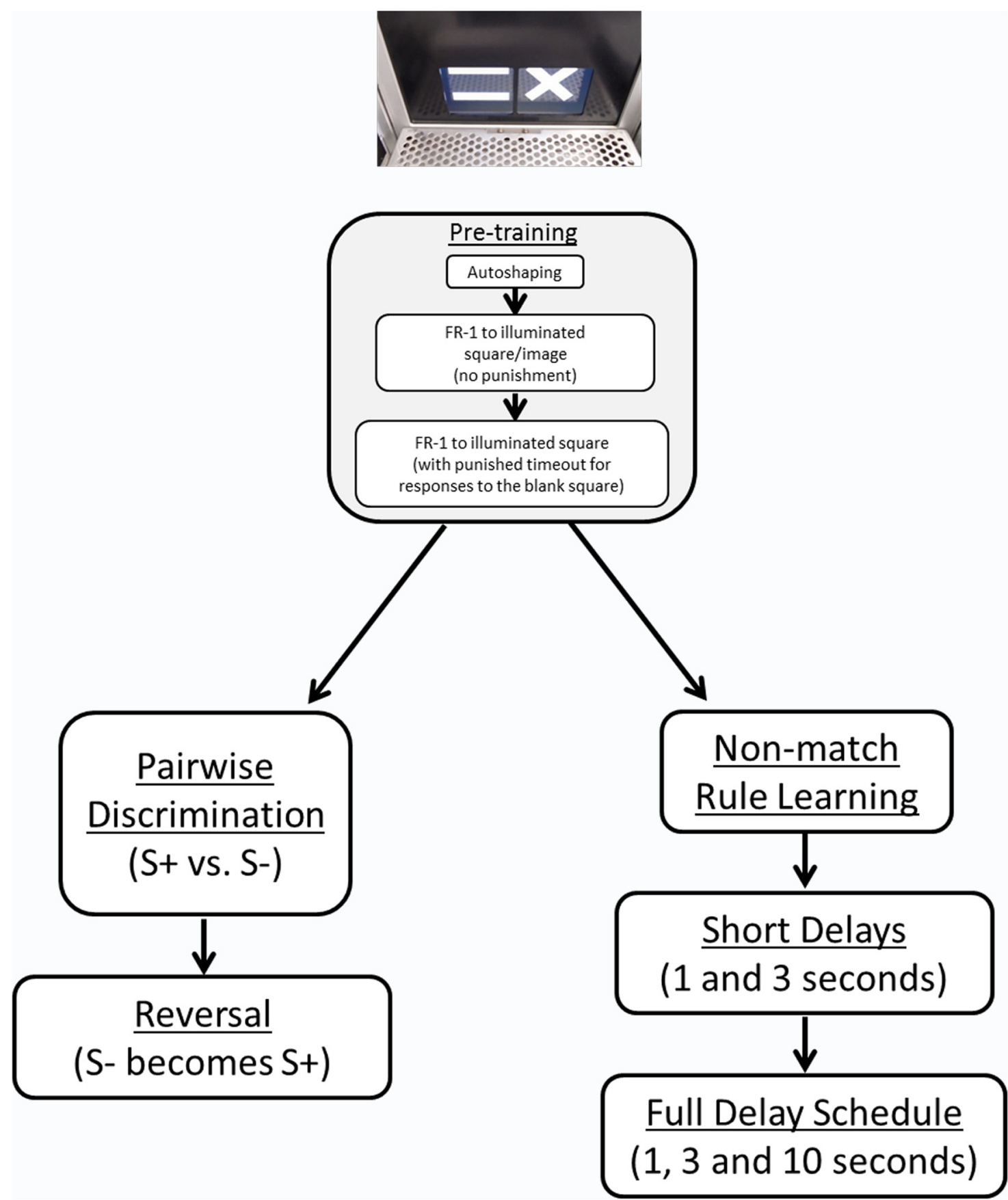

Figure 1. Diagram of touchscreen training and testing schedules. Top, An image of the touchscreen chamber is shown when configured for pairwise visual discrimination. The stages of training for pairwise visual discrimination (left) and delayed nonmatch to position (right) are shown, with similar pretraining shown in the middle. Pretraining for both tasks consists of autoshaping to the food magazine, FR-1 to the illuminated square/image (without punishment for presses to the blank space), and FR-1 to the illuminated square/image (with a punished timeout period for presses to the blank space). Pairwise visual discrimination pretraining included the following two additional stages: (1) after autoshaping, mice received $1 \mathrm{~d}$ where they received reward either for an active screen touch, or after $30 \mathrm{~s}$, whichever came first, and thereafter, all trials were "forced trials"; and (2) before punishment was added for blank responses, mice had to "initiate" trials with a nosepoke into the food magazine. Subsequently, pairwise visual discrimination consists of the discrimination between $\mathrm{S}+$ and $\mathrm{S}-$, followed by reversal of reward contingencies. The images used in the present study are shown (above). For the nonmatch task, after abbreviated pretraining, mice first learned the nonmatch rule without delays, followed by short delays (1 and $3 \mathrm{~s}$ ), and then were tested for $25 \mathrm{~d}$ at the full delay schedule $(1,3$, and 10 s delays). 
mance score calculations. Mice were trained until a performance criterion of $\geq 80 \%$ was reached for 2 days.

\section{Pairwise discrimination reversal}

After completing the acquisition phase of pairwise visual discrimination, the contingencies on the images were reversed. S+ became $\mathrm{S}-$, and vice versa. Mice were trained on reversal until a performance criterion of $\geq 80 \%$ was reached for 2 days.

\section{Delayed nonmatch to position \\ Pretraining}

Mice received $1 \mathrm{~d}$ of habituation to the touchscreen box. During habituation, the food magazine was initially filled with reinforcer and signaled with a small LED located directly above the food magazine. Each nosepoke in the food magazine initiated a new habituation trial, which consisted of a $10 \mathrm{~s} \mathrm{ITI} \mathrm{and} \mathrm{delivery} \mathrm{of} 20 \mu$ l of reinforcer. Following habituation, mice received FR-1 training, where each touch to a visual image on the screen was reinforced and paired with a brief auditory cue that acts as a CS. All images used were a filled square symbol at 100\% illumination. Image location varied randomly between the far left and far right screen locations. The first day of FR-1 training had no punishment contingencies for touching blank screen locations, where no image was displayed. Subsequent touches to blank screen locations were punished by a $20 \mathrm{~s}$ timeout. An ITI of $20 \mathrm{~s}$ followed both correct and incorrect trials. After each session, the numbers of reinforced and nonreinforced touches were recorded and used to calculate the percentage correct performance scores, as follows: \#Correct touches $\div$ \#Correct touches + \#blank touches. Training continued until a performance criterion of $\geq 80 \%$ was reached on day 2 .

\section{Nonmatch training}

The nonmatch contingency was introduced for each subject mouse when criterion was reached on the previous phase. Briefly, a sample image was presented, as in the previous phase, but a touch to the sample image triggered the activation of the reward magazine light and auditory CS. In this phase, a nosepoke in the food magazine initiated a choice between images in the two active spatial locations, (far left and far right). During the choice part of the trial, touches to the image in the other spatial location (i.e., nonmatches) were reinforced, while touches to the previous image location (i.e., matches) were punished with a $20 \mathrm{~s}$ timeout. Training continued until a performance criterion of $\geq 80 \%$ was reached for $2 \mathrm{~d}$.

\section{Initial delay training}

Next, 1 and 3 s mandatory delays were randomly assigned and imposed, after the sample image was pressed and before a food magazine entry initiated a choice. Training continued until a performance criterion of $\geq 80 \%$ at the more challenging $3 \mathrm{~s}$ delay was reached for $2 \mathrm{~d}$.

\section{Full delay testing}

The complete set of nonmatch testing instituted 1, 3, and 10 s mandatory delays, randomly assigned, after the sample image was pressed and before a food magazine entry

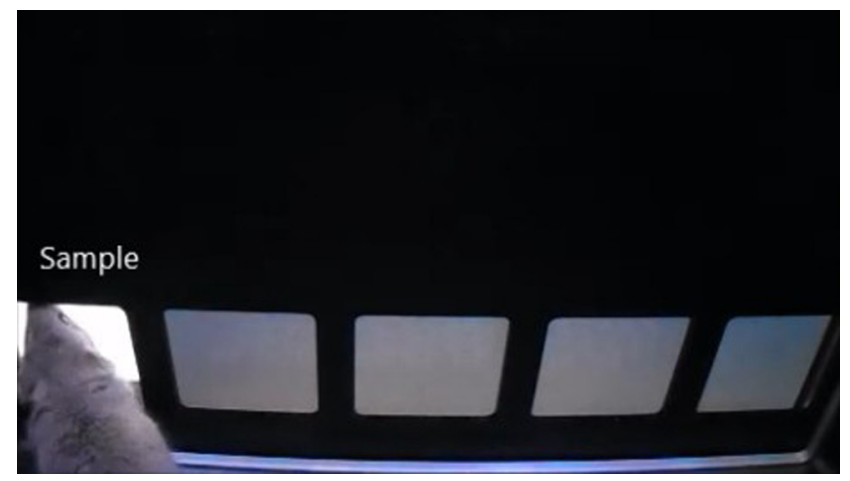

Movie 1. Performance in the touchscreen apparatus on delayed nonmatching to position in a representative FVB/AntJ mouse. Two trials are shown, and the sample appears in the left location for both. After touching the sample image, the mouse turns to the back of the chamber to nose poke in the reward tray. After a random delay $(1,3$, or $10 \mathrm{~s})$, the nose poke initiates a choice (match and nonmatch) where the image appears on both sides of the touchscreen. For both trials shown, the mouse correctly nonmatches and earns a reward.

initiated a choice. Training continued for $25 \mathrm{~d}$ for all mice (see Movie 1 for video clip of successful full delay testing).

\section{Morris water maze}

To complement the touchscreen assays, we used the standard Morris water maze task to evaluate hippocampal-dependent spatial navigation learning and memory in Fmr1 mice (Morris et al., 1982; Moser et al., 1993; Logue et al., 1997). The water maze was a $120 \mathrm{~cm}$ circular pool, filled $45 \mathrm{~cm}$ deep with $24^{\circ} \mathrm{C}$ water made opaque with nontoxic white paint (Crayola) containing a $12 \mathrm{~cm}$ platform located $1 \mathrm{~cm}$ beneath the water. External cues to aid spatial navigation included a prominent sink, computer, water temperature regulator with hose, a large black $X$ on the wall, and a yellow paper lantern hung from the ceiling. Trials were video recorded and scored by automated software (EthoVision, Noldus) for measures including latency to find the hidden platform, total distance traveled, and swim speed. Mice were trained in the hidden platform version of the Morris water maze in a manner consistent with methods that are standard in the literature (Zeng et al., 2001; Bourtchouladze et al., 2006; Daumas et al., 2008; Yang et al., 2012). Since previous literature on Morris water maze performance by Fmr1 mice has included normal performance in some reports and impaired performance in other reports (The DutchBelgian Fragile X Consortium, 1994; Kooy et al., 1996; D'Hooge et al., 1997; Paradee et al., 1999; Yan et al., 2004; Baker et al., 2010; Uutela et al., 2012; Tian et al., 2015), we chose to modify the standard procedure slightly to make it more challenging by reducing the number of daily training trials from four to three. Briefly, each Fmr1 or WT mouse was placed into the water maze, facing the wall, in one of four possible quadrant locations, which differed pseudorandomly by training day. Mice were given $60 \mathrm{~s}$ to find the hidden platform. If a subject mouse was unable to find the platform by the end of $60 \mathrm{~s}$, it was gently 
guided to the platform and allowed to rest for $\sim 10 \mathrm{~s}$ between trials. The hidden platform was in the same location, in the same quadrant, on each training day. Trials were given sequentially, with an $\sim 10$ s platform rest interval. Mice were placed under infrared heating lamps after the last trial each day to prevent hypothermia. Acquisition was assessed daily until the WT group reached a latency criterion of $<15 \mathrm{~s}$ to reach the hidden platform. Approximately $3 \mathrm{~h}$ after the last training trial, the platform was removed and mice underwent a $60 \mathrm{~s}$ probe trial to determine the amount of time spent exploring the target quadrant and the number of times the animal crossed the previous platform location and corresponding pseudoplatform locations in each quadrant. Since both genotypes reached criterion on the initial acquisition, reversal learning was then conducted with the platform in the opposite quadrant $1 \mathrm{~d}$ following the completion of acquisition. Reversal was conducted with methods identical to acquisition, with the new platform location being the only difference. Reversal was assessed daily until the WT group reached a latency criterion of $<15 \mathrm{~s}$ to reach the hidden platform. The reversal probe trial was conducted $\sim 3 \mathrm{~h}$ after the last training trial.

\section{Statistical analyses}

For pairwise visual discrimination and reversal touchscreen experiments, mixed-model $2 \times 2$ ANOVAs with genotype as a between-subjects factor and phase (acquisition or reversal) as within-subjects factors were conducted for days, and trials needed to reach criterion. One WT and two Fmr1 mice did not reach the criterion for reversal at the end of study and were removed from the ANOVAs. Additionally, the days to criterion for each genotype were compared using Mantel-Cox (log-rank) survival curve analyses separately for acquisition and reversal. For the Mantel-Cox analysis, the three mice removed from the ANOVA analyses were included as censored subjects (i.e., these animals were used to calculate the proportion reaching criterion when their data were present but were not used to calculate this number when their data were absent). Analysis of delayed nonmatch to position (DNMTP) performance with 1, 3, and 10 $s$ delays used a $3 \times 25$ within-subjects repeatedmeasures ANOVA with delay (1, 3, and 10) and day (1-25) as within-subjects factors. Repeated-measures ANOVA was conducted separately for each strain and genotype. Simple main effect tests on delays were conducted to confirm delay-dependent performance using Tukey's post hoc tests to determine which delays were significantly different from each other. Post hoc tests were conducted using Bonferroni correction for multiple comparisons to determine significant differences between 1 and $3 \mathrm{~s}$ delays, and between 1 and $10 \mathrm{~s}$ delays, for each training day. Additionally, in order to directly compare strain and genotype performance, we conducted a mixedmodel ANOVA with genotype or strain as betweensubjects factors and delay as within-subjects factors. For nonmatch to position and early delayed nonmatch to position learning, when testing was limited to 1 and $3 \mathrm{~s}$ delays, mixed-model $2 \times 2$ ANOVAs with genotype $($ WT or
$\mathrm{KO}$ ) as a between-subjects factor and phase (nonmatch learning or initial delay acquisition) as within-subjects factors were conducted for days, and trials needed to reach criterion, where normality assumptions were satisfied. For nonmatch to position and early delayed nonmatch to position learning, the days to criterion were also compared using Mantel-Cox survival curve analyses.

For Morris water maze acquisition, mixed-model $2 \times 8$ ANOVAs with genotype as a between-subjects factor and training day as a within-subjects factor were conducted for latency to find the hidden platform (in seconds), total distance traveled (in centimeters), and swim speed (in centimeters per second). Repeated-measures ANOVAs were conducted for the probe trial performance on the time spent in each quadrant, and for the number of platform crossings in each quadrant, to determine whether each genotype had used distal spatial cues to locate the hidden platform during learning. For Morris water maze reversal, the same analyses were conducted except the mixed-model ANOVAs were $2 \times 4$ with genotype as a between-subjects factor and the 4 training days as a within-subjects factor. In the event of violations of sphericity, Greenhouse-Geisser corrections were used to compute the adjusted degrees of freedom and $p$ values. For all significant probe trial ANOVAs, Dunnett's post hoc tests were used to compare quadrant time and platform crossings for target quadrant versus nontarget quadrants, and for previous platform location versus pseudoplatform locations in each quadrant.

\section{Results}

Complete statistical results for each experiment appear in Tables 1-5.

\section{Performance of Fmr1 and WT mice on pairwise discrimination and reversal learning}

Both Fmr1 WT and KO mice reached criterion in the touchscreen visual discrimination task and subsequent reversal task (Fig. 2, Table 1). Comparing the number of days required to reach criterion for each phase of pairwise discrimination revealed that there was no effect of genotype and no phase $\times$ genotype interaction (Fig. $2 A$ ). Similarly, comparing the number of trials required to reach criterion showed no effect of genotype and no phase $x$ genotype interaction (Fig. 2B). The number of trials required to reach criterion was significantly higher for reversal than acquisition, as expected. The number of days to reach criterion (survival curve analysis) for acquisition did not differ between Fmr1 and WT mice (Fig. 2C). Similarly, there were no genotype differences in the number of days required to reach criterion during reversal (Fig. 2D).

\section{FVB and B6 working memory performance in touchscreen nonmatching to position}

Inbred strains were used to develop a touchscreen task that would challenge a different cognitive domain than simple pairwise visual discrimination. To this end, we adapted standard approaches for delayed nonmatching to position. Validation used two strains of mice, C57BL/6J (B6), which is frequently used as a genetic background for targeted mutations, and FVB Pde6b + Tyrc-ch/AntJ (FVB/ 
Table 1: Statistical results for pairwise visual discrimination acquisition and reversal in Fmr1 and WT mice

\begin{tabular}{|c|c|c|c|c|c|c|c|c|}
\hline Effect & Data structure & Type of test & Power & df (between) & df (within) & $F$ & $\chi^{2}$ & $p$ \\
\hline $\begin{array}{l}\text { Pairwise discrimination } \\
\text { phase (d) }\end{array}$ & Normally distributed & $\begin{array}{l}\text { Two-factor } \\
\text { repeated-measures } \\
\text { ANOVA }\end{array}$ & 0.96 & 1 & 9 & 17.58 & & 0.002 \\
\hline $\begin{array}{l}\text { Pairwise discrimination } \\
\text { genotype (d) }\end{array}$ & Normally distributed & $\begin{array}{l}\text { Two-factor } \\
\text { repeated-measures } \\
\text { ANOVA }\end{array}$ & 0.41 & 1 & 9 & 3.78 & & 0.08 \\
\hline $\begin{array}{l}\text { Pairwise discrimination } \\
\text { interaction (d) }\end{array}$ & Normally distributed & $\begin{array}{l}\text { Two-factor } \\
\text { repeated-measures } \\
\text { ANOVA with post hoc } \\
\text { Bonferroni correction }\end{array}$ & 0.13 & 1 & 9 & 0.83 & & 0.4 \\
\hline $\begin{array}{l}\text { Pairwise discrimination } \\
\text { phase (trials) }\end{array}$ & Normally distributed & $\begin{array}{l}\text { Two-factor } \\
\text { repeated-measures } \\
\text { ANOVA }\end{array}$ & 0.62 & 1 & 9 & 6.45 & & 0.03 \\
\hline $\begin{array}{l}\text { Pairwise discrimination } \\
\text { genotype (trials) }\end{array}$ & Normally distributed & $\begin{array}{l}\text { Two-factor } \\
\text { repeated-measures } \\
\text { ANOVA }\end{array}$ & 0.16 & 1 & 9 & 1.10 & & 0.3 \\
\hline $\begin{array}{l}\text { Pairwise discrimination } \\
\text { interaction (trials) }\end{array}$ & Normally distributed & $\begin{array}{l}\text { Two-factor } \\
\text { repeated-measures } \\
\text { ANOVA }\end{array}$ & 0.06 & 1 & 9 & 0.13 & & 0.7 \\
\hline $\begin{array}{l}\text { Pairwise discrimination } \\
\text { (survival curve) }\end{array}$ & Normally distributed & $\begin{array}{l}\text { Mantel-Cox } \\
\text { test }\end{array}$ & 0.06 & 1 & & & 0.53 & 0.5 \\
\hline $\begin{array}{l}\text { Pairwise discrimination } \\
\text { reversal (survival } \\
\text { curve) }\end{array}$ & Normally distributed & $\begin{array}{l}\text { Mantel-Cox } \\
\text { test }\end{array}$ & 0.07 & 1 & & & 0.48 & 0.5 \\
\hline
\end{tabular}

AntJ), the background strain for the Fmr1 mice used in the present studies. A successfully validated working memory task should display delay-dependent performance without mediating strategies such as using body-positioning techniques to lower the working memory demand. Shaping and training required 20-85 d. Asymptotic delayschedule performance (Fig. $3 A, B$ ) was conducted for 25 d. B6 (Fig. 3A) displayed delay-dependent performance, such that the percentage correct at various delays followed the expected order of working memory load (i.e., performing better at $1>3>10$ s delays), confirmed with simple main-effect analyses (Table 2). FVB/AntJ (Fig. 3B) mice displayed delay-dependent performance in a similar fashion (i.e., $1>3>10 \mathrm{~s}$ ). Comparing daily scores at each delay revealed similar performance at 1 and $3 \mathrm{~s}$ in B6 mice on 24 of the 25 testing days, indicating that the majority of the delay-dependent performance occurred at the $10 \mathrm{~s}$ delay. FVB/AntJ mice exhibited significantly better performance at $1 \mathrm{~s}$ than at $3 \mathrm{~s}$ on 13 of $25 \mathrm{~d}$. The days required to reach criterion are graphed for illustrative purposes in Figure 3C. However, due to violations of normality, a traditional mixed-model ANOVA was not conducted for this parameter. Motivation was examined by analysis of the number of trials completed. A mixedmodel ANOVA with strain as a between-subjects factor and training phase as a within-subjects factor revealed a significant effect of strain and a significant interaction. Post hoc analysis revealed a significant difference between genotypes on acquisition of the initial delays, indicating that $\mathrm{B} 6$ mice required fewer trials to reach criterion at the initial delays ( 1 and $3 \mathrm{~s}$ ), although they required a similar number of trials for the initial acquisition of the nonmatch rule. As an additional method for calculating differences between strains on nonmatch learning and initial delay acquisition, and due to the violations of nor- mality described above, days to criterion (survival) analyses were conducted to compare the rates at which each strain met the criterion of $\geq 80 \%$ performance for $2 \mathrm{~d}$. Days to criterion analysis showed no strain differences between B6 and FVB/AntJ mice during nonmatch acquisition. During acquisition of the 1 and 3 s delays, B6 mice reached criterion significantly faster than FVB/AntJ mice. The median number of days to criterion for B6 was $4 \mathrm{~d}$, compared with $16.5 \mathrm{~d}$ for FVB/AntJ mice. Finally, to directly compare performance at each delay across strains, we ran a mixed-model ANOVA with strain as a betweensubjects factor and delay as a within-subjects factor. Direct comparison of $\mathrm{B} 6$ and FVB/AntJ mice revealed similar performance at a $1 \mathrm{~s}$ delay, but significant differences were observed at 3 and $10 \mathrm{~s}$ delays. B6 mice performed significantly better than FVB/AntJ mice at $3 \mathrm{~s}$ delay, but B6 mice performed significantly worse than FVB/AntJ mice at $10 \mathrm{~s}$ delay.

Performance of Fmr1 and WT mice in touchscreen delayed nonmatch to position task

After successful validation of the touchscreen version of delayed nonmatching to position with the B6 and FVB/ AntJ inbred strains, we proceeded to test the working memory capacity of a new cohort of Fmr1 and WT mice. After extensive shaping and training, consistent and delay-dependent performance was seen over the $25 \mathrm{~d}$ of testing (Fig. 4, Table 3). Both WT and Fmr1 mice displayed delay-dependent deficits, with better choice accuracies at $1 \mathrm{~s}$ than at $3 \mathrm{~s}$, and better choice accuracies at $3 \mathrm{~s}$ than at $10 \mathrm{~s}$. Comparing daily performance between the $1 \mathrm{~s}$ delay and each other delay revealed a significant difference between 1 and $3 \mathrm{~s}$ on 8 of $25 \mathrm{~d}$ for WT mice, and 3 of $25 \mathrm{~d}$ for Fmr1 mice, between 1 and $10 \mathrm{~s}$ for WT mice on 24 of $25 \mathrm{~d}$, and between 1 and $10 \mathrm{~s}$ for Fmr1 mice 
A

Days to Criterion

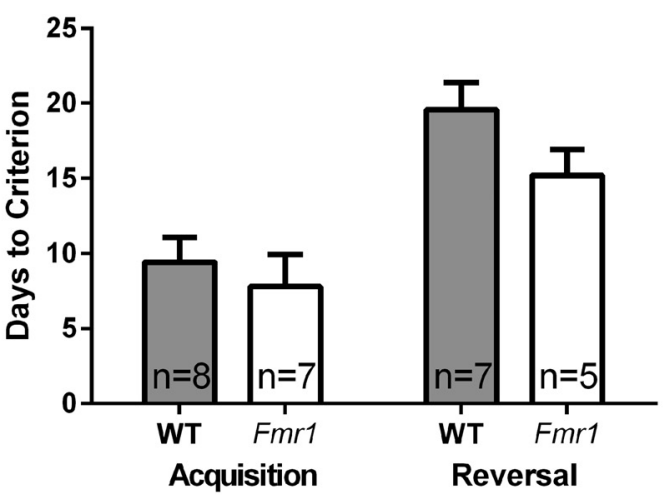

Genotype

C
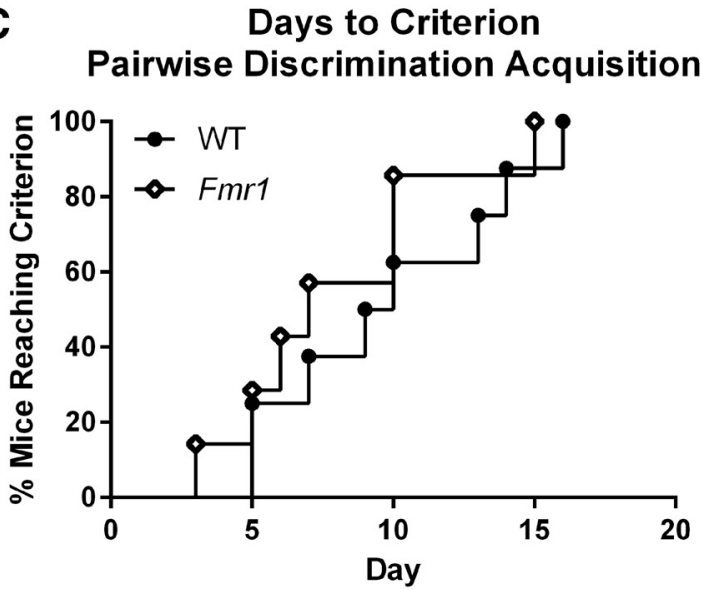

B Trials to Criterion

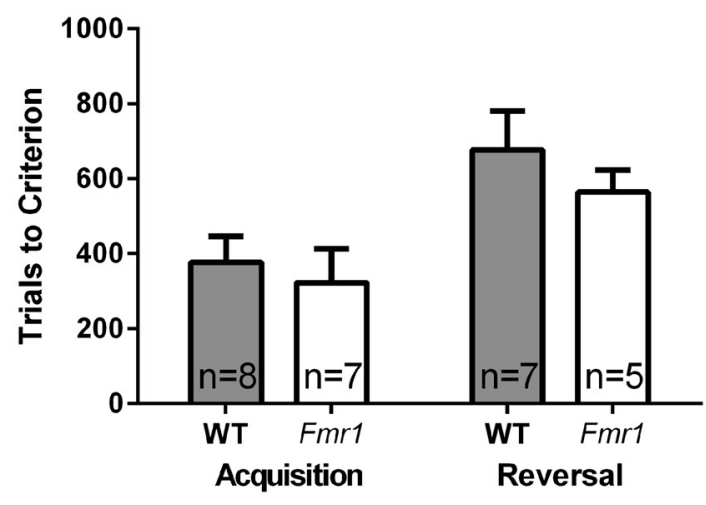

Genotype

D Pairwise Discrimination Reversal

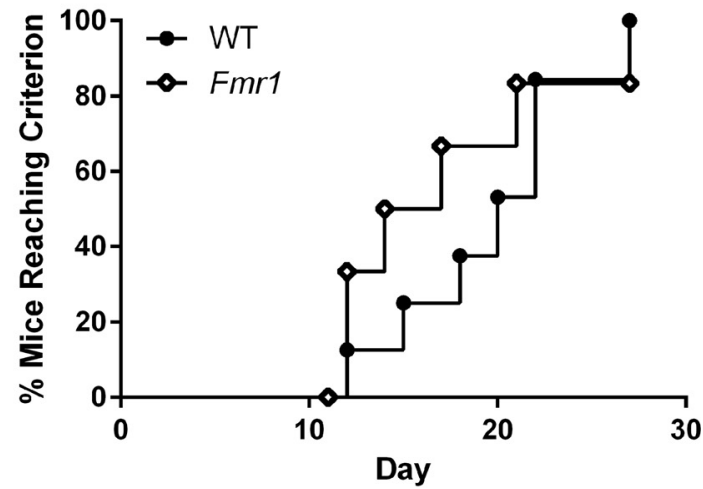

Figure 2. Pairwise visual discrimination showed no genotype differences in performance between Fmr1 and WT mice. $\boldsymbol{A}$, Days to criterion for acquisition and reversal of mice completing both phases. $\boldsymbol{B}$, Trials to criterion for acquisition and reversal of mice completing both phases. $\boldsymbol{C}$, Days to criterion for acquisition, indicating proportion of individuals that had completed training at each day (survival curve). $\boldsymbol{D}$, Days to criterion for reversal, indicating the proportion of individuals that had completed reversal at each training day (survival curve).

on 20 of $25 \mathrm{~d}$. The days to criterion (survival curve analyses) revealed that the performances of WT and Fmr1 mice were similar on both nonmatch acquisition and delay acquisition. Two Fmr1 mice exhibited spontaneous seizures in their home cages after completing days 5 and 7 of the final delay schedule. Scores from these two subject mice were removed from the final delay schedule statistics and graphs, but were retained in the acquisition dataset. Direct comparison of performance at each delay across genotype with a mixed-model ANOVA, as conducted above, revealed similar performances among genotypes at all delays.

Performance of Fmr1 and WT in Morris water maze acquisition

Both Fmr1 and WT mice on the sighted FVB/AntJ inbred background strain performed normally on Morris water maze hidden platform learning (Fig. 5, Table 4). As expected, a significant effect of training day was seen (Fig. $5 A)$. No effect of genotype and no day $\times$ genotype interaction were detected for latency measures. For distance traveled (Fig. 5B), a significant effect of training day was detected; with no effect of genotype and no day $\times$ genotype interaction. Swim speed (Fig. 5C) analysis revealed a significant effect of training day, no effect of genotype, and no day $\times$ genotype interaction. Probe trial performance $3 \mathrm{~h}$ after training on day 8 revealed significant quadrant preference (Fig. 5D) and selective target search (Fig. 5E) for both WT and Fmr1 mice, supporting the interpretation that the hidden platform task was learned using distal environmental room cues. Both Fmr1 and WT mice performed similarly on Morris water maze reversal learning (Fig. 6, Table 5). Latency to find the hidden platform during reversal learning revealed a significant effect of day, no effect of genotype, and no interaction (Fig. 6A). Distance traveled similarly showed a significant effect of day, no effect of genotype, and no interaction (Fig. 6B). Swim speed showed no effect of day, no effect of genotype, and no interaction (Fig. 6C). Probe trial performance $3 \mathrm{~h}$ after reversal training on day 4 revealed significant quadrant preference (Fig. 6D) and selective target search (Fig. 6E) for both WT and Fmr1 mice. 
A

$B 6(\mathrm{~N}=10)$

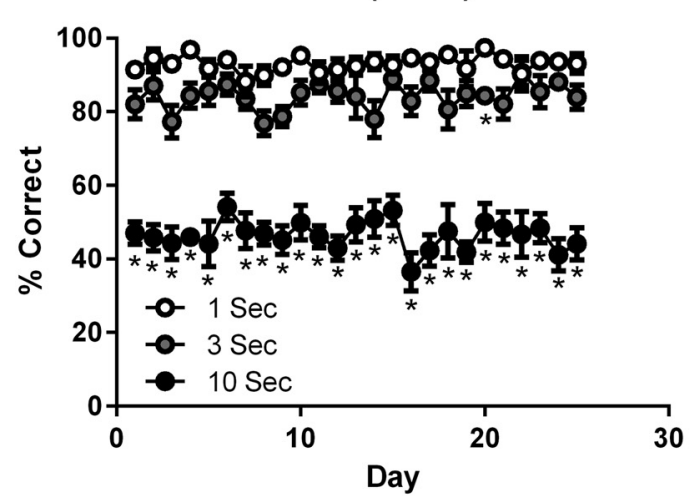

C

Days to Criterion

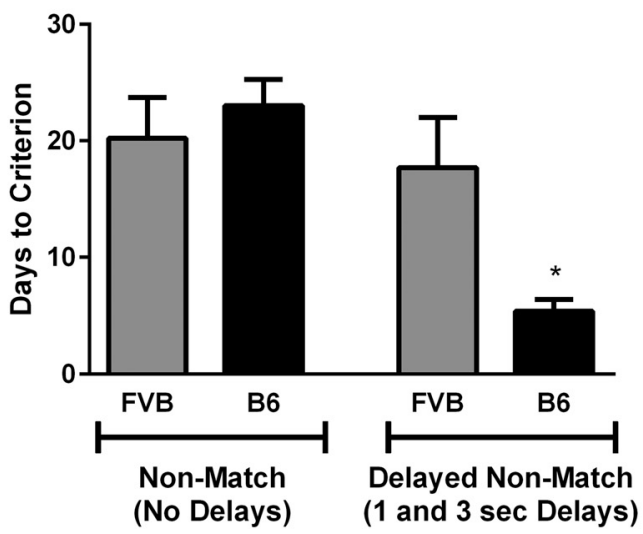

E

\section{Days to Criterion} Non-Match (No Delays)

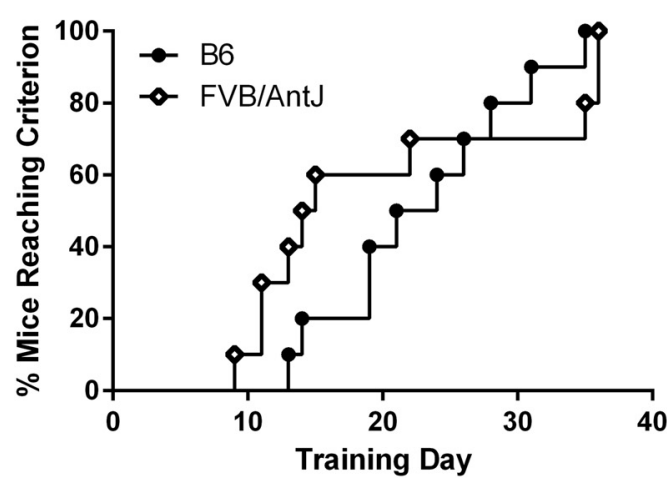

B FVB $(\mathrm{N}=10)$

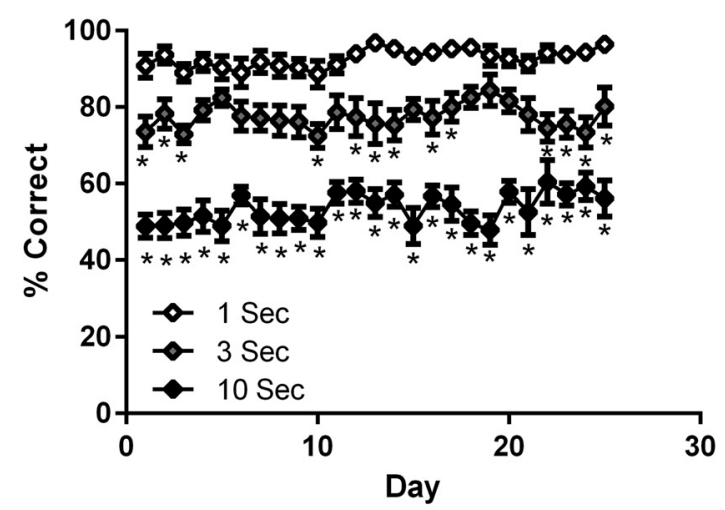

D Trials to Criterion

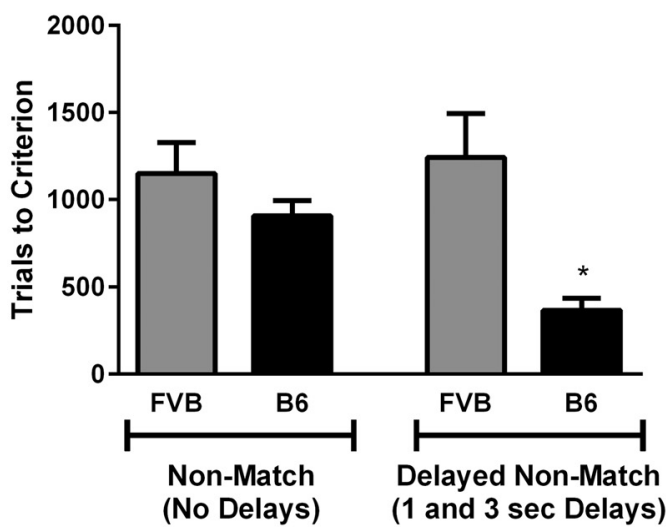

Days to Criterion
Delayed Non-Match (1 and 3 sec Delays)

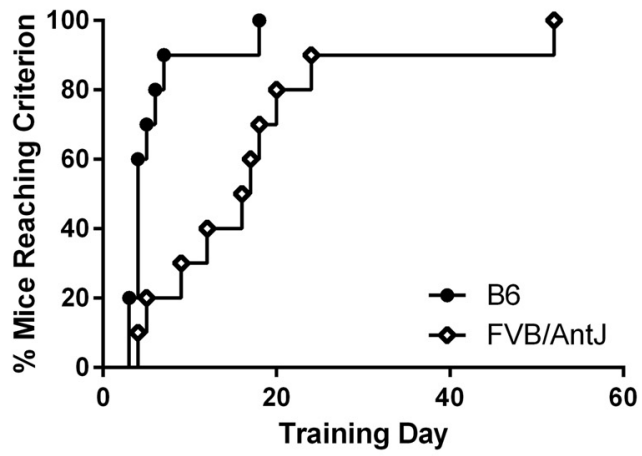

Figure 3. Validation of the delayed nonmatching to position task revealed superior working memory performance in B6 compared with FVB/AntJ inbred strains of mice. $\boldsymbol{A}$, B6 performance at 1, 3, and $10 \mathrm{~s}$ delays on the delayed nonmatching to position task. $\boldsymbol{B}$, FVB/AntJ performance at 1,3 , and 10 s delays. $\boldsymbol{C}, \boldsymbol{D}$, Days to criterion $(\boldsymbol{C})$ and trials to criterion $(\boldsymbol{D})$ for nonmatching to position rule learning (without delays), and acquisition of initial delayed nonmatching to position (1 and $3 \mathrm{~s}$ delays only). $\boldsymbol{E}$, Days to criterion (survival curves) for nonmatching rule acquisition, indicating the proportion of individuals that had completed training at each training day. $\boldsymbol{F}$, Days to criterion for the acquisition at 1 and $3 \mathrm{~s}$ delays, indicating the proportion of individuals that had completed this phase at each training day. $* p<0.05$ compared with $1 \mathrm{~s}$ delay $(\boldsymbol{A}, \boldsymbol{B}) ; * p<0.05$, strain difference for all days and trials to criterion in $\boldsymbol{C}-\boldsymbol{F}$. 
Table 2: Statistical results for nonmatching to position and delayed nonmatching to position performance in B6 and FVB mice

\begin{tabular}{|c|c|c|c|c|c|c|c|c|c|}
\hline Effect & Data structure & Type of test & Power & $\begin{array}{l}\mathrm{df} \\
\text { (between) }\end{array}$ & $\begin{array}{l}\text { df } \\
\text { (within) }\end{array}$ & $F$ & $\chi^{2}$ & $t$ & $p$ \\
\hline B6 day (DNMTP) & Sphericity passed & $\begin{array}{l}\text { Two-factor } \\
\text { repeated-measures } \\
\text { ANOVA }\end{array}$ & 0.78 & 24 & 216 & 0.97 & & & 0.5 \\
\hline By delay (DNMTP) & Sphericity passed & $\begin{array}{l}\text { Two-factor } \\
\text { repeated-measures } \\
\text { ANOVA }\end{array}$ & 1.00 & 2 & 18 & 386.96 & & & $1.67 \mathrm{E}-15$ \\
\hline B6 interaction (DNMTP) & Sphericity passed & $\begin{array}{l}\text { Two-factor } \\
\text { repeated-measures } \\
\text { ANOVA with post hoc } \\
\text { Bonferroni correction }\end{array}$ & 0.94 & 48 & 432 & 0.92 & & & 0.6 \\
\hline $\begin{array}{l}\text { Simple effects } \\
\text { test (DNMTP) }\end{array}$ & Normally distributed & $\begin{array}{l}\text { One-way ANOVA with } \\
\text { post hoc Bonferroni } \\
\text { correction }\end{array}$ & 1.00 & 2 & 18 & 387.00 & & & $1.67 \mathrm{E}-15$ \\
\hline 1 vs 3 s (DNMTP) & Normally distributed & $\begin{array}{l}\text { Post hoc } \\
\text { Bonferroni correction }\end{array}$ & 1.00 & & 9 & & & 4.99 & 0.0004 \\
\hline 3 vs 10 s (DNMTP) & Normally distributed & $\begin{array}{l}\text { Post hoc } \\
\text { Bonferroni correction }\end{array}$ & 1.00 & & 9 & & & 21.21 & 0.00000002 \\
\hline FVB day (DNMTP) & Sphericity passed & $\begin{array}{l}\text { Two-factor } \\
\text { repeated-measures } \\
\text { ANOVA }\end{array}$ & 0.73 & 24 & 216 & 0.89 & & & 0.6 \\
\hline FVB delay (DNMTP) & Sphericity passed & $\begin{array}{l}\text { Two-factor } \\
\text { repeated-measures } \\
\text { ANOVA }\end{array}$ & 1.00 & 2 & 18 & 582.60 & & & $3.22 \mathrm{E}-15$ \\
\hline FVB interaction (DNMTP) & Sphericity passed & $\begin{array}{l}\text { Two-factor } \\
\text { repeated-measures } \\
\text { ANOVA with post hoc } \\
\text { Bonferroni correction }\end{array}$ & 0.98 & 48 & 432 & 1.10 & & & 0.3 \\
\hline $\begin{array}{l}\text { Simple effects test } \\
\text { (DNMTP) }\end{array}$ & Normally distributed & $\begin{array}{l}\text { One-way ANOVA with } \\
\text { post hoc } \\
\text { Bonferroni correction }\end{array}$ & 1.00 & 2 & 18 & 582.60 & & & $3.22 \mathrm{E}-15$ \\
\hline 1 vs $3 \mathrm{~s}$ & Normally distributed & $\begin{array}{l}\text { Post hoc } \\
\text { Bonferroni correction }\end{array}$ & 1.00 & & 9 & & & 13.02 & 0.0000002 \\
\hline 3 vs $10 \mathrm{~s}$ & Normally distributed & $\begin{array}{l}\text { Post hoc Bonferroni } \\
\text { correction }\end{array}$ & 1.00 & & 9 & & & 20.81 & 0.000000007 \\
\hline $\begin{array}{l}\text { Nonmatch acquisition } \\
\text { (strain survival curve) }\end{array}$ & $\begin{array}{l}\text { Not normally } \\
\text { distributed }\end{array}$ & Mantel-Cox test & 0.11 & 1 & & & 0.03 & & 0.9 \\
\hline $\begin{array}{l}\text { Initial delay acquisition } \\
\text { (strain survival curve) }\end{array}$ & $\begin{array}{r}\text { Not normally } \\
\text { distributed }\end{array}$ & Mantel-Cox test & 0.73 & 1 & & & 7.83 & & 0.005 \\
\hline $\begin{array}{l}\text { Nonmatch and delayed } \\
\text { nonmatch acquisition } \\
\text { (strain) }\end{array}$ & Normally distributed & $\begin{array}{l}\text { Two-factor } \\
\text { repeated-measures } \\
\text { ANOVA }\end{array}$ & 0.80 & 1 & 18 & 8.70 & & & 0.009 \\
\hline $\begin{array}{l}\text { Nonmatch and delayed } \\
\text { nonmatch acquisition } \\
\text { (phase) }\end{array}$ & Normally distributed & $\begin{array}{l}\text { Two-factor } \\
\text { repeated-measures } \\
\text { ANOVA }\end{array}$ & 0.35 & 1 & 18 & 2.72 & & & 0.1 \\
\hline $\begin{array}{l}\text { Nonmatch and delayed } \\
\text { nonmatch acquisition } \\
\text { (interaction) }\end{array}$ & Normally distributed & $\begin{array}{l}\text { Two-factor } \\
\text { repeated-measures } \\
\text { ANOVA with post hoc } \\
\text { Bonferroni correction }\end{array}$ & 0.60 & 1 & 18 & 5.41 & & & 0.03 \\
\hline Strain comparison (strain) & Normally distributed & Mixed-model ANOVA & 0.05 & 1 & 18 & 0.002 & & & 0.97 \\
\hline Strain comparison (delay) & Normally distributed & Mixed-model ANOVA & 1.00 & 2 & 36 & 869.6 & & & 0.000000 \\
\hline $\begin{array}{l}\text { Strain comparison } \\
\text { (interaction) }\end{array}$ & Normally distributed & Mixed-model ANOVA & 1.00 & 2 & 36 & 20.68 & & & 0.000001 \\
\hline
\end{tabular}

\section{Discussion}

The present studies attempted to challenge the cognitive capabilities of Fmr1 mice by implementing the following four touchscreen tasks: visual discrimination, reversal of the visual discrimination, nonmatching to position, and delay-dependent nonmatching to position. All revealed normal performance in Fmr1 mice. In the present studies, normal performance was found in Fmr1 mice on touchscreen pairwise discrimination learning and reversal. Both days and trials to criterion were similar between genotypes, indicating that there were no motivational differences between genotypes. Importantly, Dickson et al. (2013) reported differences between Fmr1 and WT mice in a serial pairwise discrimination reversal task. However, these differences were selectively observed when a specific stimulus pair was used $(+$ or $X)$, but not during the reciprocal pairing (X or + ), and this effect was limited to reversal 2. Interest- 
A

WT (N=9)

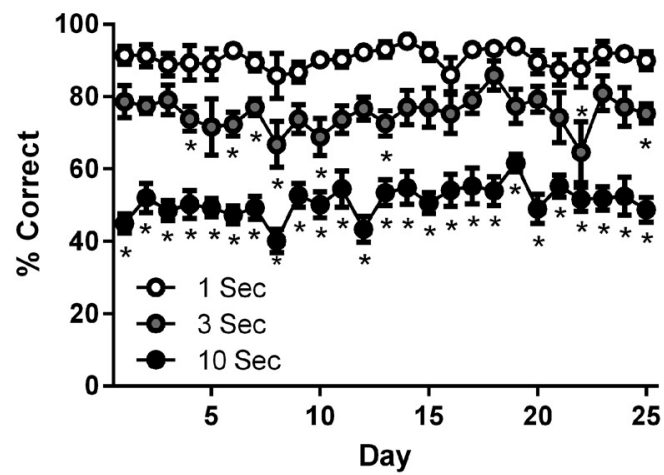

C

Days to Criterion

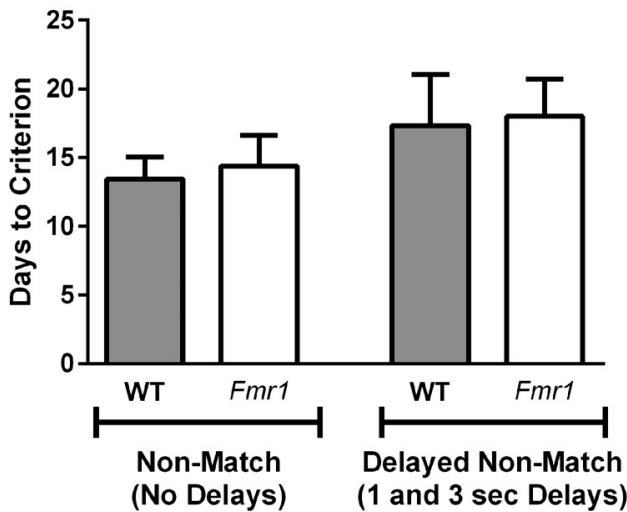

E

Days to Criterion Non-Match (No Delays)

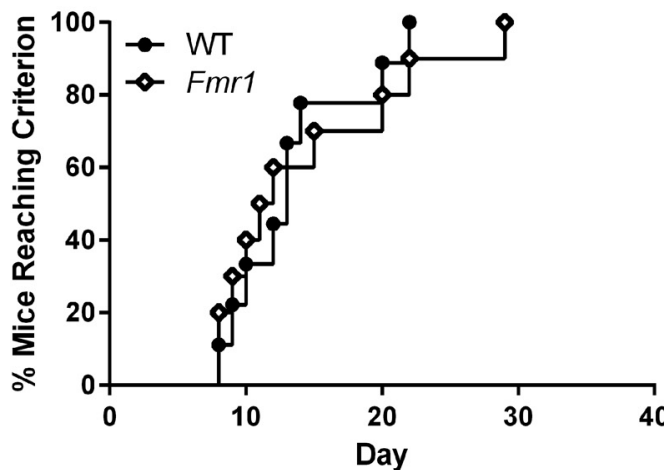

B $F m r 1(\mathrm{~N}=8)$

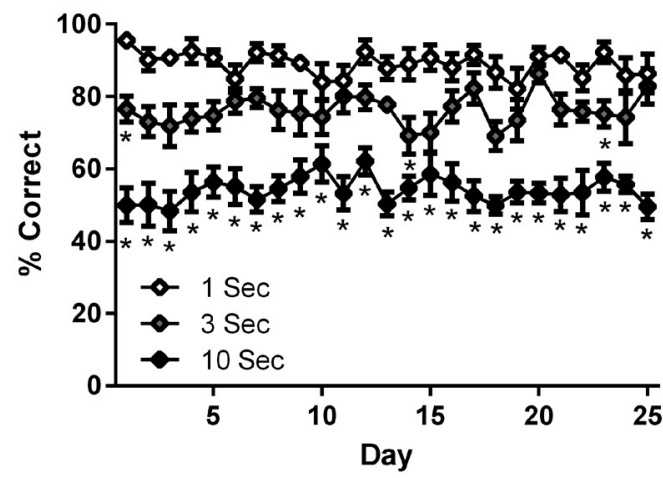

Trials to Criterion

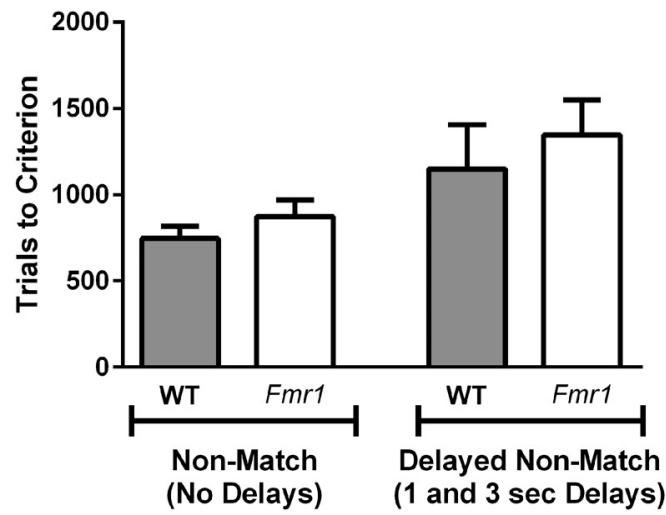

$\mathbf{F}$

Days to Criterion

Delayed Non-Match (1 and 3s Delays)

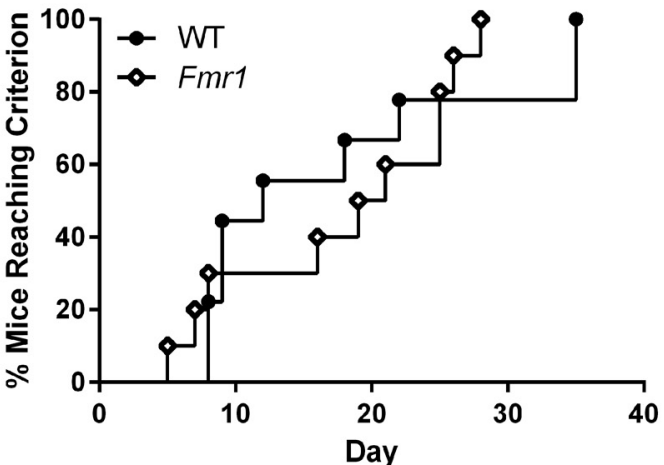

Figure 4. Delayed nonmatching to position showed no genotype differences between Fmr1 and WT mice. $\boldsymbol{A}$, WT performance on delayed nonmatching to position at 1, 3, and 10 s delays. B, Fmr1 performance on delayed nonmatching to position at 1, 3, and 10 s delays. $\boldsymbol{C}, \boldsymbol{D}$, Days to criterion $(\boldsymbol{C})$ and trials to criterion $(\boldsymbol{D})$ for rule learning in nonmatching to position (without delays) and acquisition of the initial delay periods ( 1 and $3 \mathrm{~s}$ delays only). $\boldsymbol{E}$, Days to criterion for nonmatch rule acquisition, indicating the proportion of individuals that had completed training at each training day. $\boldsymbol{F}$, Days to criterion for short delay (1 and $3 \mathrm{~s})$ acquisition, indicating the proportion of individuals that had completed this phase across time. $* p<0.05$ indicates significant difference compared with $1 \mathrm{~s}$ delay on full schedule performance.

ingly, a significant bias for $\mathrm{X}$ over + was seen on the first day of acquisition in both genotypes. In the present studies using $X$ and $=$ as the stimulus pairs, the specific stimulus rewarded during the first day of acquisition did not show a bias in our laboratory (unpublished data). As we did not conduct serial reversal, it is unclear whether an initial symbol bias could contribute to an Fmr1 deficit. 
Table 3: Statistical results for nonmatching to position and delayed nonmatching to position in Fmr1 and WT mice

\begin{tabular}{|c|c|c|c|c|c|c|c|c|c|}
\hline Effect & Data structure & Type of test & Power & df (between) & df (within) & $F$ & $\chi^{2}$ & $t$ & $p$ \\
\hline WT day (DNMTP) & Sphericity passed & Two-factor repeated-measures ANOVA & 0.92 & 24 & 192 & 1.34 & & & 0.1 \\
\hline WT delay (DNMTP) & Sphericity passed & $\begin{array}{l}\text { Two-factor } \\
\text { repeated-measures } \\
\text { ANOVA }\end{array}$ & 1.00 & 2 & 16 & 237.31 & & & $1.28 \mathrm{E}-12$ \\
\hline WT interaction (DNMTP) & Sphericity passed & $\begin{array}{l}\text { Two-factor } \\
\text { repeated-measures A } \\
\text { NOVA with post hoc } \\
\text { Bonferroni correction }\end{array}$ & 0.93 & 48 & 384 & 0.90 & & & 0.7 \\
\hline Simple effects test (DNMTP) & Normally distributed & $\begin{array}{l}\text { One-way ANOVA with } \\
\text { post hoc } \\
\text { Bonferroni correction }\end{array}$ & 1.00 & 2 & 16 & 237.30 & & & $1.28 \mathrm{E}-12$ \\
\hline 1 vs $3 \mathrm{~s}$ & Normally distributed & $\begin{array}{l}\text { Post hoc } \\
\quad \text { Bonferroni correction }\end{array}$ & 1.00 & & 8 & & & 8.25 & 0.0002 \\
\hline 3 vs $10 \mathrm{~s}$ & Normally distributed & $\begin{array}{l}\text { Post hoc } \\
\quad \text { Bonferroni correction }\end{array}$ & 1.00 & & 8 & & & 13.34 & 0.000007 \\
\hline FMR1 day (DNMTP) & Sphericity passed & $\begin{array}{l}\text { Two-factor } \\
\text { repeated-measures } \\
\text { ANOVA }\end{array}$ & 0.53 & 24 & 168 & 0.65 & & & 0.9 \\
\hline FMR1 delay (DNMTP) & Sphericity passed & $\begin{array}{l}\text { Two-factor } \\
\text { repeated-measures } \\
\text { ANOVA }\end{array}$ & 1.00 & 2 & 14 & 162.69 & & & 0.0000000002 \\
\hline FMR1 interaction (DNMTP) & Sphericity passed & $\begin{array}{l}\text { Two-factor } \\
\text { repeated-measures } \\
\text { ANOVA with post hoc } \\
\text { Bonferroni correction }\end{array}$ & 0.96 & 48 & 336 & 1.01 & & & 0.5 \\
\hline Simple effects test (DNMTP) & Normally distributed & $\begin{array}{l}\text { One-way ANOVA with } \\
\text { post hoc } \\
\text { Bonferroni correction }\end{array}$ & 1.00 & 2 & 14 & 162.70 & & & 0.0000000002 \\
\hline 1 vs $3 \mathrm{~s}$ & Normally distributed & $\begin{array}{l}\text { Post hoc Bonferroni } \\
\text { correction }\end{array}$ & 1.00 & & 7 & & & 6.57 & 0.0009 \\
\hline 3 vs $10 \mathrm{~s}$ & Normally distributed & $\begin{array}{l}\text { Post hoc Bonferroni } \\
\text { correction }\end{array}$ & 1.00 & & 7 & & & 11.26 & 0.0000003 \\
\hline $\begin{array}{l}\text { Nonmatch acquisition (genotype } \\
\text { survival curve) }\end{array}$ & Not normally distributed & Mantel-Cox test & 0.98 & 1 & & & 0.11 & & 0.7 \\
\hline $\begin{array}{l}\text { Initial delay acquisition (genotype } \\
\text { survival curve) }\end{array}$ & Not normally distributed & Mantel-Cox test & 0.95 & 1 & & & 0.13 & & 0.7 \\
\hline $\begin{array}{l}\text { Nonmatch and delayed nonmatch } \\
\text { acquisition (genotype) }\end{array}$ & Normally distributed & $\begin{array}{l}\text { Two-factor } \\
\text { repeated-measures } \\
\text { ANOVA }\end{array}$ & 0.14 & 1 & 17 & 0.84 & & & 0.4 \\
\hline $\begin{array}{l}\text { Nonmatch and delayed nonmatch } \\
\text { acquisition (phase) }\end{array}$ & Normally distributed & $\begin{array}{l}\text { Two-factor } \\
\text { repeated-measures } \\
\text { ANOVA }\end{array}$ & 0.69 & 1 & 17 & 6.85 & & & 0.02 \\
\hline $\begin{array}{l}\text { Nonmatch and delayed nonmatch } \\
\text { acquisition (interaction) }\end{array}$ & Normally distributed & $\begin{array}{l}\text { Two-factor } \\
\text { repeated-measures } \\
\text { ANOVA }\end{array}$ & 0.05 & 1 & 17 & 0.05 & & & 0.8 \\
\hline Genotype comparison (genotype) & Normally distributed & Mixed-model ANOVA & 0.09 & 1 & 15 & 0.4272 & & & 0.5 \\
\hline Genotype comparison (delay) & Normally distributed & Mixed-model ANOVA & 1.00 & 2 & 30 & 393.9 & & & 0.000000 \\
\hline $\begin{array}{l}\text { Genotype comparison } \\
\text { (interaction) }\end{array}$ & Normally distributed & Mixed-model ANOVA & 0.28 & 2 & 30 & 1.43 & & & 0.3 \\
\hline
\end{tabular}

No differences in trials to criterion were observed in initial nonmatch rule learning or initial delay acquisition, which indicates equal motivation between Fmr1 and WT mice, similar to what was observed during touchscreen pairwise visual discrimination learning. A comparison of WT and Fmr1 performance at the individual delays across the $25 \mathrm{~d}$ of testing under the complete delay schedule (1, 3 , and $10 \mathrm{~s})$ revealed no genotype differences at any delay. Performance at $1 \mathrm{~s}$ reveals very high performance ( $\sim 90 \%$ correct) in both genotypes when working memory was virtually untaxed. Performance at $3 \mathrm{~s}$ was significantly worse than $1 \mathrm{~s}$ performance ( $75 \%$ correct), suggesting that these task parameters were sufficiently challenging to test moderate working memory load in these mice. Performance at $10 \mathrm{~s}$ was near chance (50\% correct) in both genotypes, indicating that $10 \mathrm{~s}$ is sufficient to produce a floor effect in this task. Furthermore, while touchscreen testing in rats on nonmatch tasks has successfully used trial-unique delayed nonmatching-to-location (TUNL) to more completely prevent mediating strategies (Talpos et al., 2010), this strategy has only recently been successfully applied to mice after substantial modifications (Kim et al., 2015). The TUNL task in mice has the potential limitation of the subject using mediating strategies. Locations of the sample in positions in the center of the array are inherently more difficult than sample locations at sides of the array (Kim et al., 2015). While mediating strategies are possible (i.e., orienting body position toward target location) when non-trial-unique choice locations are used, these were not observed in the present study. The $10 \mathrm{~s}$ delays were sufficient to produce chance performance, which would not be the case if mediating strategies were being used. Further, asymptotic performance was sustained over the course of $25 \mathrm{~d}$ of final delay schedule 
A

Latency
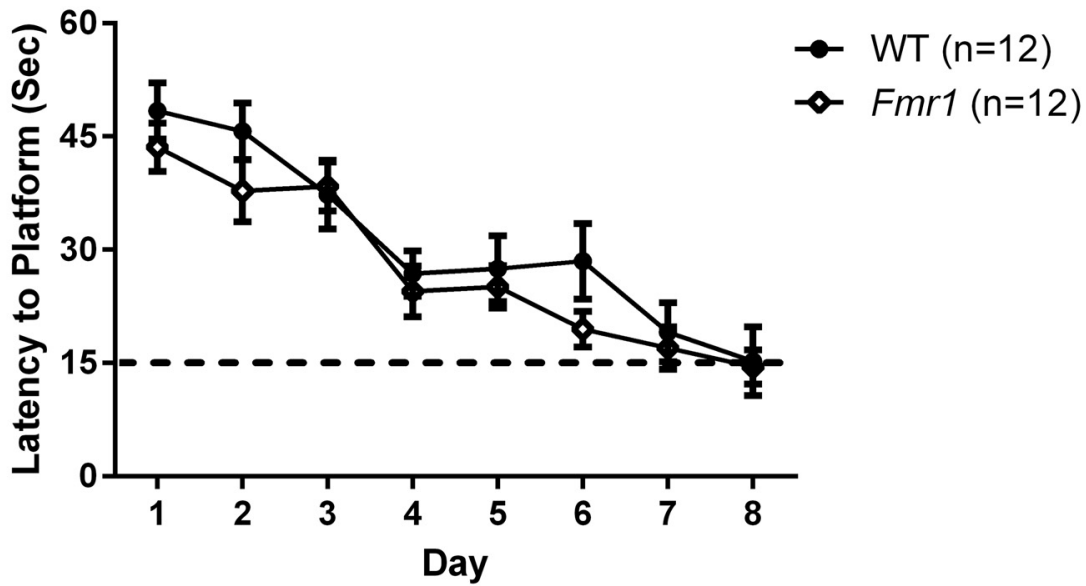

B

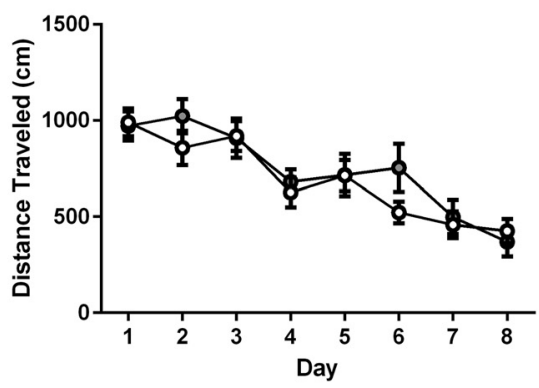

D

Quadrant Preference

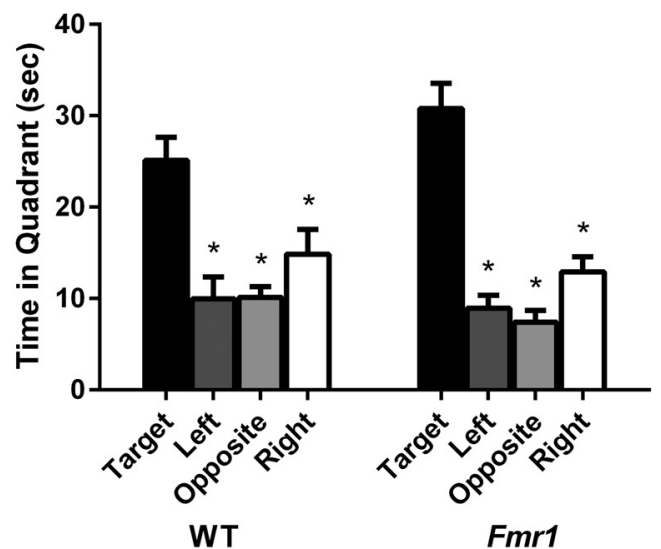

C

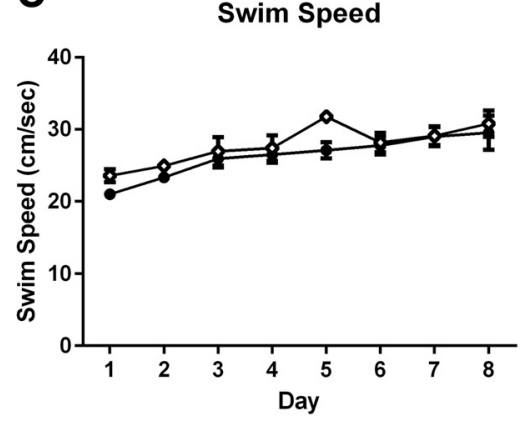

E

Platform Crossings

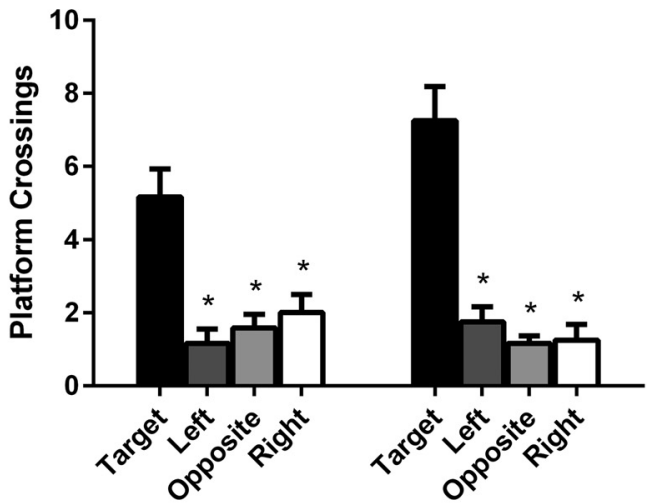

WT

Fmr1

Figure 5. Acquisition of Morris water maze hidden platform spatial navigation learning showed no genotype differences between Fmr1 and WT mice. Both genotypes displayed normal performance during acquisition. $\boldsymbol{A}$, Latency to find the hidden platform. $\boldsymbol{B}$, Distance traveled during the training trials. C, Swim speed during the training trials. $\boldsymbol{D}$, Quadrant time during the $60 \mathrm{~s}$ probe trial, begun $3 \mathrm{~h}$ after the last training trial. $\boldsymbol{E}$, Platform location crossings during the $60 \mathrm{~s}$ probe trial. $* p<0.05$ indicates more time in the previously trained platform quadrant than in the other three quadrants, and more crossings over the previous platform location than over the other three pseudolocations.

testing, which also suggests a lack of mediating strategies.

The present studies also compared performance of the FVB/AntJ background strain in the delayed nonmatching to position task to performance of the C57BL/6J inbred strain in order to determine the baseline capabilities of the Fmr1 background strain. Interestingly, reaching criterion on the initial delays of 1 and $3 \mathrm{~s}$ took significantly longer in the FVB/AntJ strain than in B6 mice. Further, once the complete delay schedule was implemented $(1,3$, and 10 
Table 4: Statistical results for Morris water maze (MWM) acquisition performance in Fmr1 and WT mice

\begin{tabular}{|c|c|c|c|c|c|c|c|}
\hline Effect & Data structure & Type of test & Power & df (between) & df (within) & $F$ & $P$ \\
\hline $\begin{array}{l}\text { MWM acquisition } \\
\text { latency-genotype }\end{array}$ & Sphericity violated & Mixed-model ANOVA & 0.19 & 1 & 22 & 1.31 & 0.3 \\
\hline $\begin{array}{l}\text { MWM acquisition } \\
\text { latency-day }\end{array}$ & Sphericity violated & $\begin{array}{l}\text { Mixed-model ANOVA } \\
\text { with Greenhouse-Geisser } \\
\text { correction }\end{array}$ & 1.00 & 4.63 & 101.95 & 25.73 & $5.55 \mathrm{E}-16$ \\
\hline $\begin{array}{l}\text { MWM acquisition } \\
\text { latency-interaction }\end{array}$ & Sphericity violated & $\begin{array}{l}\text { Mixed-model ANOVA } \\
\text { with Greenhouse-Geisser } \\
\text { correction }\end{array}$ & 0.26 & 4.63 & 101.95 & 0.61 & 0.7 \\
\hline $\begin{array}{l}\text { MWM acquisition } \\
\text { distance-day }\end{array}$ & Sphericity passed & Mixed-model ANOVA & 1.00 & 7 & 154 & 16.26 & $6.66 \mathrm{E}-16$ \\
\hline $\begin{array}{l}\text { MWM acquisition } \\
\text { distance-interaction }\end{array}$ & Sphericity passed & Mixed-model ANOVA & 0.36 & 7 & 154 & 0.85 & 0.5 \\
\hline $\begin{array}{l}\text { MWM acquisition } \\
\text { speed-genotype }\end{array}$ & Sphericity violated & Mixed-model ANOVA & 0.32 & 1 & 22 & 2.47 & 0.1 \\
\hline WT quadrant time & Sphericity passed & $\begin{array}{l}\text { Repeated-measures ANOVA } \\
\text { with post hoc Dunnett's } \\
\text { test }\end{array}$ & 0.97 & 3 & 33 & 7.19 & 0.0008 \\
\hline $\begin{array}{l}\text { FMR1 quadrant } \\
\text { time }\end{array}$ & Sphericity violated & $\begin{array}{l}\text { Repeated-measures ANOVA } \\
\text { with Greenhouse-Geisser } \\
\text { correction and post hoc } \\
\text { Dunnett's test }\end{array}$ & 1.00 & 1.65 & 18.16 & 25.04 & 0.00001 \\
\hline $\begin{array}{l}\text { WT platform } \\
\text { crossings }\end{array}$ & Sphericity passed & $\begin{array}{l}\text { Repeated-measures ANOVA } \\
\text { with post hoc } \\
\text { Dunnett's test }\end{array}$ & 0.99 & 3 & 33 & 12.54 & 0.00001 \\
\hline $\begin{array}{l}\text { FMR1 platform } \\
\text { crossings }\end{array}$ & Sphericity violated & $\begin{array}{l}\text { Repeated-measures ANOVA } \\
\text { with Greenhouse-Geisser } \\
\text { correction and post hoc } \\
\text { Dunnett's test }\end{array}$ & 1.00 & 1.36 & 14.98 & 28.16 & 0.00003 \\
\hline
\end{tabular}

s), the FVB mice performed significantly worse than B6 mice at $3 \mathrm{~s}$, demonstrating the sensitivity of our methods to detect performance deficits. Results with the inbred strains confirmed that a delay of $3 \mathrm{~s}$ was sufficient to detect performance deficits, as the performances of inbred strains, Fmr1, and WT were all well above chance levels.

Given the variable literature on Fmr1 mouse performance on Morris water maze spatial learning and memory (The Dutch-Belgian Fragile X Consortium, 1994; Kooy et al., 1996; D'Hooge et al., 1997; Paradee et al., 1999; Yan et al., 2004; Baker et al., 2010; Uutela et al., 2012; Tian et al., 2015), we conducted this task using methods that detected deficits in other lines of mutant mice (Holmes et al., 2001; Rustay et al., 2005; Brielmaier et al., 2012), with slight modifications to make the task more difficult. No genotype differences between Fmr1 and WT mice were observed on acquisition, probe trial, reversal, or reversal probe trial. Swim speed was similar between genotypes during acquisition and reversal learning, indicating intact motor abilities. Interestingly, with one exception (Baker et al., 2010), deficits that were previously observed in Fmr1 mice during water maze acquisition were not found in probe trial performance (The Dutch-
Belgian Fragile X Consortium, 1994; Kooy et al., 1996; D'Hooge et al., 1997; Paradee et al., 1999; Uutela et al., 2012), indicating the uniform capability to use distal spatial cues to navigate toward a hidden platform. Further, most of the water maze reports used the B6 background (The Dutch-Belgian Fragile X Consortium, 1994; Kooy et al., 1996; D'Hooge et al., 1997; Paradee et al., 1999; Uutela et al., 2012), avoiding the potential concern of retinal degeneration in the FVB/NJ background. While there are some reports of background strain-dependent phenotypes in the Fmr1 mouse (Spencer et al., 2011), a recent review of the effect of background strain on cognitive abilities in Fmr1 mice did not reveal consistency in strain-specific cognitive deficits (Kazdoba et al., 2016). While we cannot exclude that there might be water maze conditions that would reveal a deficit in this task, such as a larger pool size or colder water, our standard testing conditions did not reveal a deficit, as would be expected from a strong mouse model of FXS.

Since the original generation of the Fmr1 knock-out mouse model of fragile X syndrome in 1994, hundreds of publications have evaluated the behavioral phenotypes of Fmr1 mice, on both B6 and FVB genetic backgrounds. In most cases, normal performance on learning and memory 
A

Latency
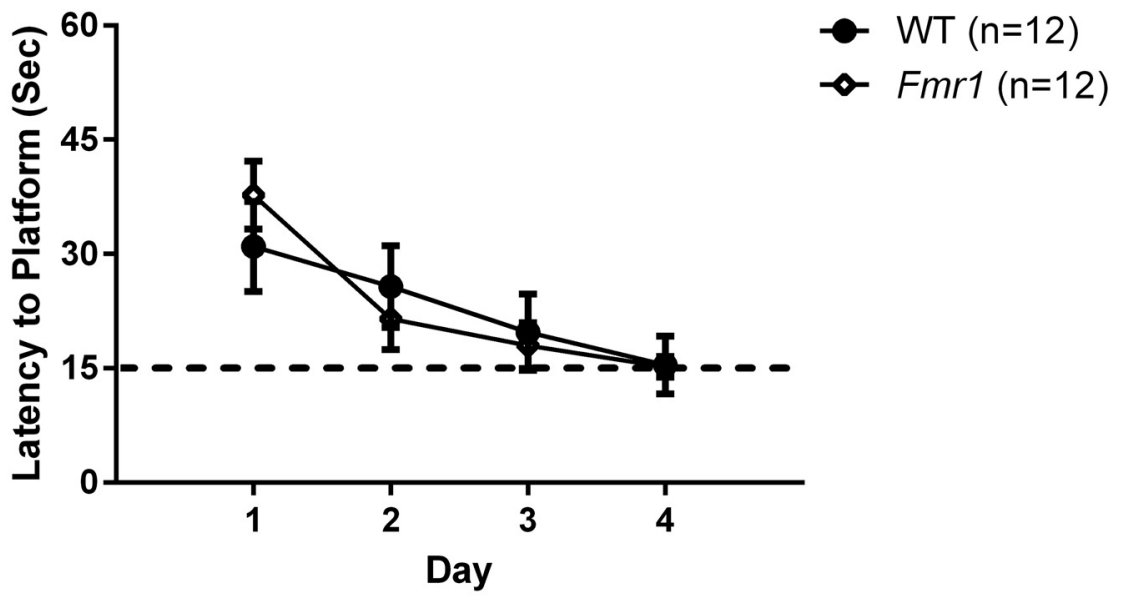

B

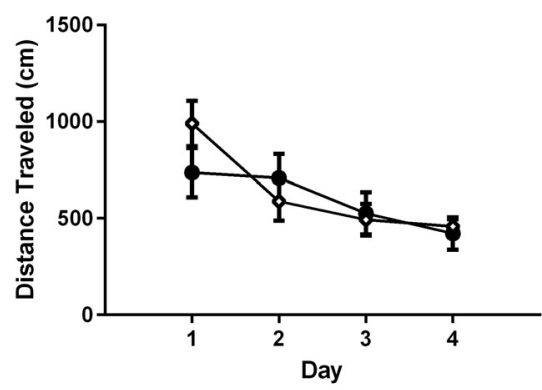

D

Quadrant Preference (Reversal)

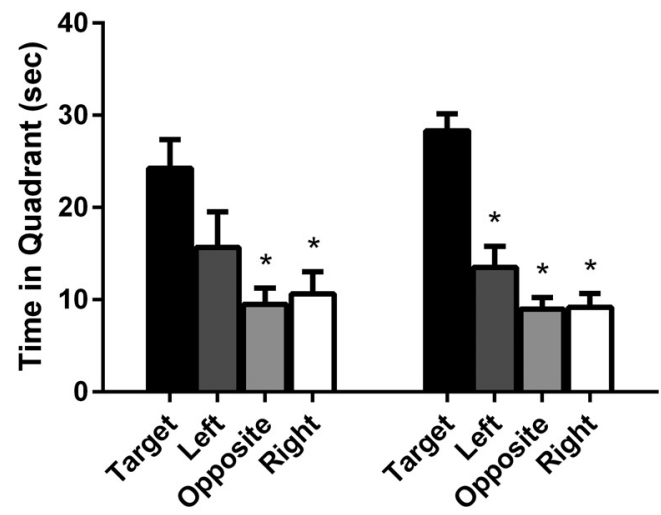

WT
Distance

Fmr1

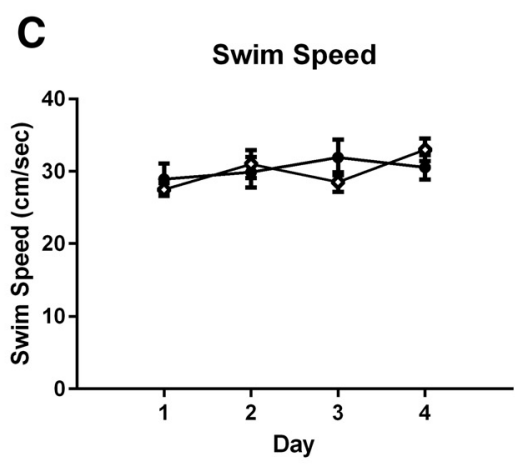

E

Platform Crossings (Reversal)

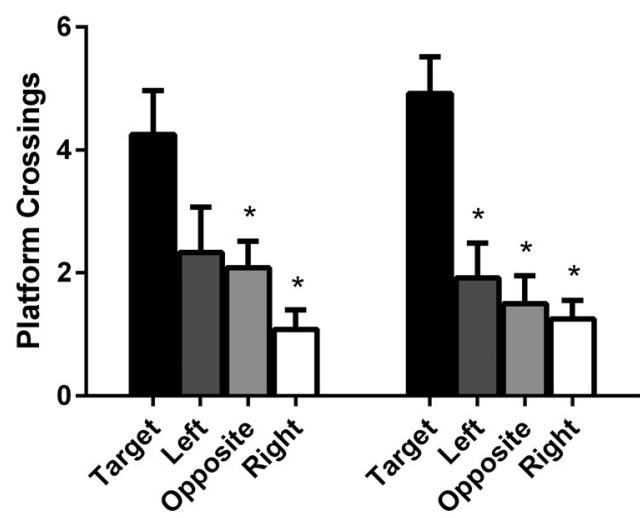

WT
Fmr1

Figure 6. Reversal of Morris water maze hidden platform spatial navigation learning showed no genotype differences between Fmr1 and WT mice. Both genotypes displayed normal performance during reversal. $\boldsymbol{A}$, Latency to find the hidden platform. $\boldsymbol{B}$, Distance traveled during the training trials. $\boldsymbol{C}$, Swim speed during the training trials. $\boldsymbol{D}$, Quadrant time during the $60 \mathrm{~s}$ probe trial, begun $3 \mathrm{~h}$ after the last training trial. $\boldsymbol{E}$, Platform location crossings during the $60 \mathrm{~s}$ probe trial. $* p<0.05$ indicates more time in the previously trained platform quadrant than in the other three quadrants, or more crossings over the previous platform location than over the other three pseudolocations.

tasks was apparent in well validated and established gold standard mouse cognitive assays; however, these findings varied considerably. Some groups showed deficits in passive avoidance (Qin et al., 2002; Dölen et al., 2007;
Yuskaitis et al., 2010; Veeraragavan et al., 2011a; Ding et al., 2014; Michalon et al., 2014), while others did not (The Dutch-Belgian Fragile X Consortium, 1994; Veeraragavan et al., 2011b, 2012). Deficits in contextual, 
Table 5: Statistical results for Morris water maze reversal performance in Fmr1 and WT mice

\begin{tabular}{|c|c|c|c|c|c|c|c|}
\hline Effect & Data structure & Type of test & Power & df (between) & df (within) & $F$ & $p$ \\
\hline $\begin{array}{l}\text { Latency reversal- } \\
\text { genotype }\end{array}$ & Sphericity violated & Mixed-model ANOVA & 0.05 & 1 & 22 & 0.001 & 0.97 \\
\hline Latency reversal-day & Sphericity violated & $\begin{array}{l}\text { Mixed-model ANOVA } \\
\text { with Greenhouse-Geisser } \\
\text { correction }\end{array}$ & 1.00 & 2.16 & 47.58 & 10.12 & 0.0002 \\
\hline $\begin{array}{l}\text { Latency reversal- } \\
\text { interaction }\end{array}$ & Sphericity violated & $\begin{array}{l}\text { Mixed-model ANOVA } \\
\text { with Greenhouse-Geisser } \\
\text { correction }\end{array}$ & 0.22 & 2.16 & 47.58 & 0.82 & 0.5 \\
\hline $\begin{array}{l}\text { Distance reversal- } \\
\text { genotype }\end{array}$ & Sphericity violated & Mixed-model ANOVA & 0.07 & 1 & 22 & 0.16 & 0.7 \\
\hline Distance reversal-day & Sphericity violated & $\begin{array}{l}\text { Mixed-model ANOVA } \\
\text { with Greenhouse-Geisser } \\
\text { correction }\end{array}$ & 0.99 & 2.17 & 47.66 & 7.91 & 0.0008 \\
\hline $\begin{array}{l}\text { Distance reversal- } \\
\text { interaction }\end{array}$ & Sphericity violated & $\begin{array}{l}\text { Mixed-model ANOVA } \\
\text { with Greenhouse-Geisser } \\
\text { correction }\end{array}$ & 0.37 & 2.17 & 47.66 & 1.46 & 0.2 \\
\hline Speed reversal-genotype & Sphericity passed & Mixed-model ANOVA & 0.05 & 1 & 22 & 0.04 & 0.8 \\
\hline Speed reversal-day & Sphericity passed & Mixed-model ANOVA & 0.41 & 3 & 66 & 1.63 & 0.2 \\
\hline $\begin{array}{l}\text { Speed reversal- } \\
\text { interaction }\end{array}$ & Sphericity passed & Mixed-model ANOVA & 0.33 & 3 & 66 & 1.28 & 0.3 \\
\hline $\begin{array}{l}\text { WT reversal } \\
\text { quadrant time }\end{array}$ & Sphericity violated & $\begin{array}{l}\text { Repeated-measures ANOVA } \\
\text { with Greenhouse-Geisser } \\
\text { correction and post hoc } \\
\text { Dunnett's test }\end{array}$ & 0.80 & 1.94 & 21.37 & 4.08 & 0.3 \\
\hline $\begin{array}{l}\text { FMR1 reversal } \\
\text { quadrant time }\end{array}$ & Sphericity violated & $\begin{array}{l}\text { Repeated-measures ANOVA } \\
\text { with Greenhouse-Geisser } \\
\text { correction and post hoc } \\
\text { Dunnett's test }\end{array}$ & 1.00 & 2.02 & 22.24 & 20.84 & 0.000008 \\
\hline $\begin{array}{l}\text { WT reversal } \\
\text { platform crossings }\end{array}$ & Sphericity passed & $\begin{array}{l}\text { Repeated-measures ANOVA } \\
\text { with post hoc } \\
\text { Dunnett's test }\end{array}$ & 0.91 & 3 & 33 & 5.41 & 0.004 \\
\hline $\begin{array}{l}\text { FMR1 reversal } \\
\text { platform crossings }\end{array}$ & Sphericity violated & $\begin{array}{l}\text { Repeated-measures ANOVA } \\
\text { with Greenhouse-Geisser } \\
\text { correction and post hoc } \\
\text { Dunnett's test }\end{array}$ & 1.00 & 1.97 & 21.68 & 9.91 & 0.0009 \\
\hline
\end{tabular}

cued, and/or trace-cued fear conditioning were reported by some groups (Paradee et al., 1999; Zhao et al., 2005; Auerbach et al., 2011; Ding et al., 2014), while other researchers failed to detect fear conditioning deficits (Dobkin et al., 2000; Peier et al., 2000; Van Dam et al., 2000; Baker et al., 2010; Uutela et al., 2012). Morris water maze acquisition and reversal were impaired in Fmr1 mice in some studies (The Dutch-Belgian Fragile X Consortium, 1994; Kooy et al., 1996; D’Hooge et al., 1997; Baker et al., 2010; Tian et al., 2015), while not in others (Paradee et al., 1999; Yan et al., 2004; Uutela et al., 2012). It is possible that the small dimensions of the specific apparatus used here $(120 \mathrm{~cm})$ contributed to the lack of observed phenotype. Novel object recognition and object location memory were detected in multiple reports (Ventura et al., 2004; Busquets-Garcia et al., 2013; King and Jope, 2013; Seese et al., 2014), but not in all (Yan et al., 2004). Five-choice serial reaction time has shown both deficiencies and normal performance in Fmr1 mice (Moon et al., 2006; Krueger et al., 2011; Kramvis et al., 2013; Sidorov et al., 2014). As mentioned previously, background strain differences have been reported in Fmr1 mice in some tasks (Paradee et al., 1999; Dobkin et al., 2000; Spencer et al., 2011); however, cognitive testing has not revealed a consistent background strain-dependent phenotype. Very large group sizes used in some of the cited publications (The DutchBelgian Fragile X Consortium, 1994; Kooy et al., 1996; D’Hooge et al., 1997; Baker et al., 2010) may have been needed to detect subtle cognitive deficits in standard learning and memory paradigms. Because of these diverse findings, we sought to develop more sensitive touchscreen tasks to detect robust cognitive deficits in Fmr1 mice on the FVB/AntJ background, which could be used in preclinical discovery of therapeutics.

In conclusion, touchscreen tasks for mouse models of neurodevelopmental disorders with intellectual disabilities offer advantages in designing tasks that allow the researcher to titrate the demands on working memory and evaluate various cognitive domains, using equipment similar to that used in human subjects with intellectual disabilities (Green et al., 2009; Van der Molen et al., 2010; van Nieuwpoort et al., 2011; Berry-Kravis et al., 2013; Díez-Juan et al., 2014). Our findings with a new touchscreen DNMTP task revealed that Fmr1 mutant mice on the FVB/AntJ background performed as well as their WT controls on a delay-dependent working memory task. Normal performance by Fmr1 mice on a variety of touchscreen and other types of learning tasks confirms rather than resolves the conundrum that the Fmr1 mouse model does not recapitulate the cognitive profile of human FXS, 
at least on this array of behavioral tasks. It remains possible that our tasks, while designed to challenge working memory capacity, may have been insufficiently difficult to reveal cognitive deficits in Fmr1 mice. Unfortunately, the present findings confirmed the general lack of significant cognitive phenotypes in the Fmr1 mouse model of FXS. The lack of robust cognitive phenotypes, even on a challenging working memory task, is an important contribution because it suggests that the Fmr1 mouse model may not be as useful as originally predicted.

\section{References}

Auerbach BD, Osterweil EK, Bear MF (2011) Mutations causing syndromic autism define an axis of synaptic pathophysiology. Nature 480:63-68. CrossRef Medline

Baker KB, Wray SP, Ritter R, Mason S, Lanthorn TH, Savelieva KV (2010) Male and female Fmr1 knockout mice on C57 albino background exhibit spatial learning and memory impairments. Genes Brain Behav 9:562-574. CrossRef Medline

Baker S, Hooper S, Skinner M, Hatton D, Schaaf J, Ornstein P, Bailey D (2011) Working memory subsystems and task complexity in young boys with Fragile X syndrome. J Intellect Disabil Res 55:1929. CrossRef Medline

Bernardo A, McCord M, Troen AM, Allison JD, McDonald MP (2007) Impaired spatial memory in APP-overexpressing mice on a homocysteinemia-inducing diet. Neurobiol Aging 28:1195-1205. CrossRef Medline

Berry-Kravis E, HessI D, Abbeduto L, Reiss AL, Beckel-Mitchener A, Urv TK (2013) Outcome measures for clinical trials in fragile $X$ syndrome. J Dev Behav Pediatr 34:508-522. CrossRef Medline

Bourtchouladze R, Patterson SL, Kelly MP, Kreibich A, Kandel ER, Abel T (2006) Chronically increased Gsalpha signaling disrupts associative and spatial learning. Learn Mem 13:745-752. CrossRef Medline

Brielmaier J, Matteson PG, Silverman JL, Senerth JM, Kelly S, Genestine M, Millonig JH, DiCicco-Bloom E, Crawley JN (2012) Autism-relevant social abnormalities and cognitive deficits in engrailed-2 knockout mice. PLoS One 7:e40914. CrossRef Medline

Brigman JL, Rothblat LA (2008) Stimulus specific deficit on visual reversal learning after lesions of medial prefrontal cortex in the mouse. Behav Brain Res 187:405-410. CrossRef Medline

Brigman JL, Bussey TJ, Saksida LM, Rothblat LA (2005) Discrimination of multidimensional visual stimuli by mice: intra- and extradimensional shifts. Behav Neurosci 119:839-842. CrossRef Medline

Brigman JL, Ihne J, Saksida LM, Bussey TJ, Holmes A (2009) Effects of subchronic phencyclidine (PCP) treatment on social behaviors, and operant discrimination and reversal learning in C57BL/6J mice. Front Behav Neurosci 3:2. CrossRef Medline

Brigman JL, Feyder M, Saksida LM, Bussey TJ, Mishina M, Holmes A (2008) Impaired discrimination learning in mice lacking the NMDA receptor NR2A subunit. Learn Mem 15:50-54. CrossRef Medline

Busquets-Garcia A, Gomis-González M, Guegan T, Agustín-Pavón C, Pastor A, Mato S, Pérez-Samartín A, Matute C, de la Torre R, Dierssen M, Maldonado R, Ozaita A (2013) Targeting the endocannabinoid system in the treatment of fragile $X$ syndrome. Nat Med 19:603-607. CrossRef Medline

Bussey TJ, Saksida LM, Rothblat LA (2001) Discrimination of computer-graphic stimuli by mice: a method for the behavioral characterization of transgenic and gene-knockout models. Behav Neurosci 115:957-960. Medline

Bussey TJ, Holmes A, Lyon L, Mar AC, McAllister KA, Nithianantharajah J, Oomen CA, Saksida LM (2012) New translational assays for preclinical modelling of cognition in schizophrenia: the touchscreen testing method for mice and rats. Neuropharmacology 62:1191-1203. CrossRef Medline
Cianchetti C, Sannio-Fancello G, Fratta AL, Manconi F, Orano A, Pischedda MP, Pruna D, Spinicci G, Archidiacono N, Filippi G (1991) Neuropsychological, psychiatric, and physical manifestations in 149 members from 18 fragile X families. Am J Med Genet 40:234-243. CrossRef Medline

D'Hooge R, Nagels G, Franck F, Bakker CE, Reyniers E, Storm K, Kooy RF, Oostra BA, Willems PJ, De Deyn PP (1997) Mildly impaired water maze performance in male Fmr1 knockout mice. Neuroscience 76:367-376.

Daumas S, Sandin J, Chen KS, Kobayashi D, Tulloch J, Martin SJ, Games D, Morris RG (2008) Faster forgetting contributes to impaired spatial memory in the PDAPP mouse: deficit in memory retrieval associated with increased sensitivity to interference? Learn Mem 15:625-632. CrossRef

Dickson PE, Corkill B, McKimm E, Miller MM, Calton MA, Goldowitz D, Blaha CD, Mittleman G (2013) Effects of stimulus salience on touchscreen serial reversal learning in a mouse model of fragile $X$ syndrome. Behav Brain Res 252:126-135. CrossRef

Díez-Juan M, Schneider A, Phillips T, Lozano R, Tassone F, Solomon M, Hagerman RJ (2014) Parent-delivered touchscreen intervention for children with fragile $X$ syndrome. Intractable Rare Dis Res 3:166-177. CrossRef Medline

Ding Q, Sethna F, Wang H (2014) Behavioral analysis of male and female Fmr1 knockout mice on C57BL/6 background. Behav Brain Res 271:72-78. CrossRef Medline

Dobkin C, Rabe A, Dumas R, El Idrissi A, Haubenstock H, Brown WT (2000) Fmr1 knockout mouse has a distinctive strain-specific learning impairment. Neuroscience 100:423-429. CrossRef

Dölen G, Osterweil E, Rao BS, Smith GB, Auerbach BD, Chattarji S, Bear MF (2007) Correction of fragile $X$ syndrome in mice. Neuron 56:955-962. CrossRef Medline

Dowdy-Sanders NC, Wenger GR (2006) Working memory in the Ts65Dn mouse, a model for Down syndrome. Behav Brain Res 168:349-352. CrossRef Medline

Estapé N, Steckler T (2002) Cholinergic blockade impairs performance in operant DNMTP in two inbred strains of mice. Pharmacol Biochem Behav 72:319-334. Medline

Feng Y, Zhang F, Lokey LK, Chastain JL, Lakkis L, Eberhart D, Warren ST (1995) Translational suppression by trinucleotide repeat expansion at FMR1. Science 268:731-734. Medline

Freund LS, Reiss AL (1991) Cognitive profiles associated with the $\mathrm{fra}(\mathrm{X})$ syndrome in males and females. Am J Med Genet 38:542547. CrossRef Medline

Goto K, Kurashima R, Watanabe S (2010a) Delayed matching-toposition performance in C57BL/6N mice. Behav Processes 84: 591-597. CrossRef Medline

Goto K, Kurashima R, Gokan H, Inoue N, Ito I, Watanabe S (2010b) Left-right asymmetry defect in the hippocampal circuitry impairs spatial learning and working memory in iv mice. PLoS One 5:e15468. CrossRef Medline

Graybeal C, Feyder M, Schulman E, Saksida LM, Bussey TJ, Brigman JL, Holmes A (2011) Paradoxical reversal learning enhancement by stress or prefrontal cortical damage: rescue with BDNF. Nat Neurosci 14:1507-1509. CrossRef Medline

Graybeal C, Bachu M, Mozhui K, Saksida LM, Bussey TJ, Sagalyn E, Williams RW, Holmes A (2014) Strains and stressors: an analysis of touchscreen learning in genetically diverse mouse strains. PLoS One 9:e87745. CrossRef Medline

Green CR, Mihic AM, Nikkel SM, Stade BC, Rasmussen C, Munoz DP, Reynolds JN (2009) Executive function deficits in children with fetal alcohol spectrum disorders (FASD) measured using the Cambridge Neuropsychological Tests Automated Battery (CANTAB). J Child Psychol Psychiatry 50:688-697. CrossRef Medline

Holmes A, Hollon TR, Gleason TC, Liu Z, Dreiling J, Sibley DR, Crawley JN (2001) Behavioral characterization of dopamine D5 receptor null mutant mice. Behav Neurosci 115:1129-1144. Medline

Kazdoba TM, Leach PT, Crawley JN (2016) Behavioral phenotypes of genetic mouse models of autism. Genes Brain Behav 15:7-26. CrossRef 
Kim C, Romberg C, Hvoslef-Eide M, Oomen C, Mar A, Heath C, Berthiaume A-A, Bussey T, Saksida L (2015) Trial-unique, delayed nonmatching-to-location (TUNL) touchscreen testing for mice: sensitivity to dorsal hippocampal dysfunction. Psychopharmacology 232:3935-3945. CrossRef Medline

King MK, Jope RS (2013) Lithium treatment alleviates impaired cognition in a mouse model of fragile X syndrome. Genes Brain Behav 12:723-731. CrossRef Medline

Kogan CS, Boutet I, Cornish K, Graham GE, Berry-Kravis E, Drouin A, Milgram NW (2009) A comparative neuropsychological test battery differentiates cognitive signatures of Fragile $X$ and Down syndrome. J Intellect Disabil Res 53:125-142. CrossRef Medline

Kooy RF (2003) Of mice and the fragile X syndrome. Trends Genet 19:148-154. Medline

Kooy RF, D'Hooge R, Reyniers E, Bakker CE, Nagels G, De Boulle K, Storm K, Clincke G, De Deyn PP, Oostra BA, Willems PJ (1996) Transgenic mouse model for the fragile $X$ syndrome. Am $\mathrm{J}$ Med Genet 64:241-245. CrossRef Medline

Kramvis I, Mansvelder HD, Loos M, Meredith R (2013) Hyperactivity, perseveration and increased responding during attentional rule acquisition in the fragile $X$ mouse model. Front Behav Neurosci 7:172. CrossRef Medline

Krueger DD, Osterweil EK, Chen SP, Tye LD, Bear MF (2011) Cognitive dysfunction and prefrontal synaptic abnormalities in a mouse model of fragile $X$ syndrome. Proc Natl Acad Sci U S A 108:2587-2592. CrossRef

Krueger DD, Howell JL, Hebert BF, Olausson P, Taylor JR, Nairn AC (2006) Assessment of cognitive function in the heterozygous reeler mouse. Psychopharmacology 189:95-104. CrossRef Medline

Krueger DD, Howell JL, Oo H, Olausson P, Taylor JR, Nairn AC (2009) Prior chronic cocaine exposure in mice induces persistent alterations in cognitive function. Behav Pharmacol 20:695-704. CrossRef Medline

Logue SF, Paylor R, Wehner JM (1997) Hippocampal lesions cause learning deficits in inbred mice in the Morris water maze and conditioned-fear task. Behav Neurosci 111:104-113. Medline

Maes B, Fryns JP, Van Walleghem M, Van den Berghe H (1994) Cognitive functioning and information processing of adult mentally retarded men with fragile-X syndrome. Am J Med Genet 50:190200. CrossRef Medline

Mar AC, Horner AE, Nilsson SR, Alsiö J, Kent BA, Kim CH, Holmes A, Saksida LM, Bussey TJ (2013) The touchscreen operant platform for assessing executive function in rats and mice. Nat Protoc 8:1985-2005. CrossRef Medline

Martin LA, Escher T, Goldowitz D, Mittleman G (2004) A relationship between cerebellar Purkinje cells and spatial working memory demonstrated in a lurcher/chimera mouse model system. Genes Brain Behav 3:158-166. CrossRef

Michalon A, Bruns A, Risterucci C, Honer M, Ballard TM, Ozmen L, Jaeschke G, Wettstein JG, von Kienlin M, Künnecke B, Lindemann L (2014) Chronic metabotropic glutamate receptor 5 inhibition corrects local alterations of brain activity and improves cognitive performance in fragile X mice. Biol Psychiatry 75:189-197. CrossRef Medline

Moon J, Beaudin AE, Verosky S, Driscoll LL, Weiskopf M, Levitsky DA, Crnic LS, Strupp BJ (2006) Attentional dysfunction, impulsivity, and resistance to change in a mouse model of fragile $X$ syndrome. Behav Neurosci 120:1367-1379. CrossRef Medline

Morris RGM, Garrud P, Rawlins JNP, O'Keefe J (1982) Place navigation impaired in rats with hippocampal lesions. Nature 297:681683. Medline

Moser E, Moser MB, Andersen P (1993) Spatial learning impairment parallels the magnitude of dorsal hippocampal lesions, but is hardly present following ventral lesions. J Neurosci 13:3916-3925.

Oomen CA, Hvoslef-Eide M, Heath CJ, Mar AC, Horner AE, Bussey TJ, Saksida LM (2013) The touchscreen operant platform for testing working memory and pattern separation in rats and mice. Nat Protoc 8:2006-2021. CrossRef Medline

Paradee W, Melikian HE, Rasmussen DL, Kenneson A, Conn PJ, Warren ST (1999) Fragile X mouse: strain effects of knockout phenotype and evidence suggesting deficient amygdala function. Neuroscience 94:185-192. Medline

Peier AM, Mcllwain KL, Kenneson A, Warren ST, Paylor R, Nelson DL (2000) (Over)correction of FMR1 deficiency with YAC transgenics: behavioral and physical features. Hum Mol Genet 9:1145-1159. Medline

Qin M, Kang J, Smith CB (2002) Increased rates of cerebral glucose metabolism in a mouse model of fragile $X$ mental retardation. Proc Natl Acad Sci U S A 99:15758-15763. CrossRef

Romberg C, Mattson MP, Mughal MR, Bussey TJ, Saksida LM (2011) Impaired attention in the 3xTgAD mouse model of Alzheimer's disease: rescue by donepezil (Aricept). J Neurosci 31:3500-3507. CrossRef

Rustay NR, Wrenn CC, Kinney JW, Holmes A, Bailey KR, Sullivan TL, Harris AP, Long KC, Saavedra MC, Starosta G, Innerfield CE, Yang RJ, Dreiling JL, Crawley JN (2005) Galanin impairs performance on learning and memory tasks: findings from galanin transgenic and GAL-R1 knockout mice. Neuropeptides 39:239-243. CrossRef Medline

Seese RR, Wang K, Yao YQ, Lynch G, Gall CM (2014) Spaced training rescues memory and ERK $1 / 2$ signaling in fragile $X$ syndrome model mice. Proc Natl Acad Sci U S A 111:16907-16912. CrossRef Medline

Sidorov MS, Krueger DD, Taylor M, Gisin E, Osterweil EK, Bear MF (2014) Extinction of an instrumental response: a cognitive behavioral assay in Fmr1 knockout mice. Genes Brain Behav 13:451458.

Silverman JL, Gastrell PT, Karras MN, Solomon M, Crawley JN (2015) Cognitive abilities on transitive inference using a novel touchscreen technology for mice. Cereb Cortex 25:1133-1142. CrossRef Medline

Spencer CM, Alekseyenko O, Hamilton SM, Thomas AM, Serysheva E, Yuva-Paylor LA, Paylor R (2011) Modifying behavioral phenotypes in Fmr1KO mice: genetic background differences reveal autistic-like responses. Autism Res 4:40-56. CrossRef Medline

Sutcliffe JS, Nelson DL, Zhang F, Pieretti M, Caskey CT, Saxe D, Warren ST (1992) DNA methylation represses FMR-1 transcription in fragile $X$ syndrome. Hum Mol Genet 1:397-400. Medline

Talpos JC, McTighe SM, Dias R, Saksida LM, Bussey TJ (2010) Trial-unique, delayed nonmatching-to-location (TUNL): a novel, highly hippocampus-dependent automated touchscreen test of location memory and pattern separation. Neurobiol Learn Mem 94:341-352. CrossRef Medline

The Dutch-Belgian Fragile X Consortium (1994) Fmr1 knockout mice: a model to study fragile $X$ mental retardation. Cell 78:23-33. CrossRef Medline

Tian M, Zeng Y, Hu Y, Yuan X, Liu S, Li J, Lu P, Sun Y, Gao L, Fu D, Li Y, Wang S, McClintock SM (2015) 7, 8-Dihydroxyflavone induces synapse expression of AMPA GluA1 and ameliorates cognitive and spine abnormalities in a mouse model of fragile $X$ syndrome. Neuropharmacology 89:43-53. CrossRef Medline

Uutela M, Lindholm J, Louhivuori V, Wei H, Louhivuori LM, Pertovaara A, Akerman K, Castrén E, Castrén ML (2012) Reduction of BDNF expression in Fmr1 knockout mice worsens cognitive deficits but improves hyperactivity and sensorimotor deficits. Genes Brain Behav 11:513-523. CrossRef Medline

Van Dam D, D'Hooge R, Hauben E, Reyniers E, Gantois I, Bakker CE, Oostra BA, Kooy RF, De Deyn PP (2000) Spatial learning, contextual fear conditioning and conditioned emotional response in Fmr1 knockout mice. Behav Brain Res 117:127-136. Medline

Van der Molen MJ, Huizinga M, Huizenga HM, Ridderinkhof KR, Van der Molen MW, Hamel BJ, Curfs LM, Ramakers GJ (2010) Profiling Fragile $X$ Syndrome in males: strengths and weaknesses in cognitive abilities. Res Dev Disabil 31:426-439. CrossRef Medline

van Nieuwpoort IC, Deijen JB, Curfs LM, Drent ML (2011) The relationship between IGF-I concentration, cognitive function and quality of life in adults with Prader-Willi syndrome. Horm Behav 59:444-450. CrossRef Medline

Veeraragavan S, Bui N, Perkins JR, Yuva-Paylor LA, Carpenter RL, Paylor R (2011a) Modulation of behavioral phenotypes by a mus- 
carinic M1 antagonist in a mouse model of fragile $X$ syndrome. Psychopharmacology (Berl) 217:143-151. CrossRef Medline

Veeraragavan S, Bui N, Perkins JR, Yuva-Paylor LA, Paylor R (2011b) The modulation of fragile $X$ behaviors by the muscarinic M4 antagonist, tropicamide. Behav Neurosci 125:783-790. CrossRef Medline

Veeraragavan S, Graham D, Bui N, Yuva-Paylor LA, Wess J, Paylor R (2012) Genetic reduction of muscarinic M4 receptor modulates analgesic response and acoustic startle response in a mouse model of fragile $X$ syndrome (FXS). Behav Brain Res 228:1-8. CrossRef Medline

Ventura R, Pascucci T, Catania MV, Musumeci SA, Puglisi-Allegra S (2004) Object recognition impairment in Fmr1 knockout mice is reversed by amphetamine: involvement of dopamine in the medial prefrontal cortex. Behav Pharmacol 15:433-442. Medline

Whitney KN, Wenger GR (2012) Working memory in the aged Ts65Dn mouse, a model for Down syndrome. Behav Brain Res 232:202209. CrossRef Medline

Yan QJ, Asafo-Adjei PK, Arnold HM, Brown RE, Bauchwitz RP (2004) A phenotypic and molecular characterization of the fmr1-tm1Cgr fragile X mouse. Genes Brain Behav 3:337-359. CrossRef Medline
Yang M, Bozdagi O, Scattoni ML, Wohr M, Roullet FI, Katz AM, Abrams DN, Kalikhman D, Simon H, Woldeyohannes L, Zhang JY, Harris MJ, Saxena R, Silverman JL, Buxbaum JD, Crawley JN (2012) Reduced excitatory neurotransmission and mild autismrelevant phenotypes in adolescent Shank3 null mutant mice. J Neurosci 32:6525-6541. CrossRef

Yuskaitis CJ, Mines MA, King MK, Sweatt JD, Miller CA, Jope RS (2010) Lithium ameliorates altered glycogen synthase kinase-3 and behavior in a mouse model of fragile $X$ syndrome. Biochem Pharmacol 79:632-646. CrossRef

Zeng $\mathrm{H}$, Chattarji S, Barbarosie M, Rondi-Reig L, Philpot BD, Miyakawa T, Bear MF, Tonegawa $S$ (2001) Forebrain-specific calcineurin knockout selectively impairs bidirectional synaptic plasticity and working/episodic-like memory. Cell 107:617-629. Medline

Zhao MG, Toyoda H, Ko SW, Ding HK, Wu LJ, Zhuo M (2005) Deficits in trace fear memory and long-term potentiation in a mouse model for fragile X syndrome. J Neurosci 25:7385-7392. CrossRef Medline 